PETER HOOPER

Federal Reserve Board

CATHERINE L. MANN

Federal Reserve Board

\title{
Exchange Rate Pass-through in the 1980s: The Case of U.S. Imports of Manufactures
}

MovEMENTS IN the exchange rate of the dollar are now widely perceived to have less impact on U.S. import prices than they had at the beginning of this decade. If that perception is accurate, a depreciation of the dollar may be less effective in bringing about adjustment in the real external balance, but it is also less likely to fuel inflation. We address three questions in this report. What are current estimates of the timing and magnitude of the effect of changes in the exchange rate on import prices? Has this relationship changed over the past decade? What would be the implications for U.S. import prices of a further fall in the dollar?

Over the years, a substantial body of empirical research has addressed the question of the transmission of nominal exchange rate changes to import prices, either directly or as part of a discussion of how exchange rate changes might affect the trade balance. ${ }^{1}$ In fact, it is almost a rite of

We have benefited especially from discussions with William R. Melick, as well as from comments and suggestions by William F. Branson, Ellen E. Meade, Edwin M. Truman, and members of the Brookings Panel. Kathryn A. Larin provided substantial research assistance and prepared the data appendix. Catherine Mann worked on this paper while on the staff of the World Bank. The views expressed here are our own and do not necessarily reflect the views of the Federal Reserve Board or the World Bank.

1. A partial list includes Branson (1972); Clark (1974); Magee (1974); Kreinin (1977); Hooper and Lowrey (1979); Spitaller (1980); Woo (1984); Krugman and Baldwin (1987); Helkie and Hooper (1987, 1989); Mastropasqua and Vona (1988); Cline (1989); Hooper and Mann (1989a); and Moffet (1989). 
spring at April meetings of the Brookings Panel to discuss what has come to be known as exchange rate pass-through. Many studies analyze the pass-through relationship for total (nonoil) imports. Some calculate it directly from movements in import prices and exchange rates. Others employ more complete models that include the exchange rate, a proxy for foreign costs, and occasionally other variables, such as commodity prices. In general, estimates of the portion of exchange rate changes transmitted into import prices have hovered around 80 percent, although some of the more recent studies find figures closer to 50 percent. ${ }^{2}$ The time it takes for pass-through to be completed ranges from several months to several years. ${ }^{3}$

Some of the older studies and a substantial fraction of the most recent work have analyzed pass-through using disaggregated, industry-level data. ${ }^{4}$ The general conclusion of this work is that pass-through varies across industries. In some cases, disaggregating the data appears to reduce total pass-through and reduce the length of the lags. This work also highlights the importance of the choice, construction, and aggregation of price and cost data to analyze pass-through.

Our own analysis continues in this empirical tradition. We build on the recent work, consolidating and extending it in several ways. First, we focus only on imports of manufactures. The theoretical underpinnings of the pass-through literature emphasize microeconomic models of imperfect competition, product differentiation, and price discrimination. Markets for manufactured goods are more likely to exhibit these characteristics than are those for more basic commodities. Nevertheless, because manufactured goods account for about 80 percent of total U.S. merchandise imports, our analysis clearly can contribute to the macroeconomic debate.

Second, we construct country-specific indexes of foreign production costs, including the costs of labor, raw materials, and energy, rather than using the broad consumer or wholesale price indexes that other studies have employed. Such indexes may have become unsatisfactory proxies for costs of production, in part because of their relative insensitivity to movements in the prices of raw materials and energy. The six

2. For a recent estimate, see Moffet (1989).

3. Spitaller (1980); Krugman and Baldwin (1987).

4. Isard (1974); Kravis and Lipsey (1978); Kreinin (1977); Mann and Meade (1987); Knetter (1989); Ohno (1988); and Marston (1989). 
industrial countries and three developing countries included in our sample account for about 75 percent of U.S. imports of manufactured goods.

Third, we measure prices using a fixed-weight index instead of the implicit deflator for nonoil imports used by Baldwin, Helkie-Hooper, and Krugman-Baldwin, among others. The variable-weight import deflator has tended to understate actual increases in import prices in recent years.

What follows is divided into five parts. First we present the analytical framework for our empirical analysis of pass-through and derive the equations used in estimation. Second, we describe our choice and construction of data on prices, costs, exchange rates, and other variables, and review the movements in these series, as well as foreign profit margins, over the floating exchange rate period. This analysis illustrates how the choice of import price data and foreign cost data can substantially affect the perceived movement in foreign profit margins and hence passthrough. It also considers the extent to which Japanese exporters price differently in the U.S. market than they do in all of their foreign markets on average. Next we estimate the pass-through coefficients on exchange rates and foreign costs and test whether these empirical relationships have changed over the 1980s. This analysis focuses on both the average price of total U.S. imports of manufactured goods and the price of imports of manufactures from Japan, the only country for which bilateral data for prices of U.S. imports of manufactures are available. Then, taking the estimation results, we ask what might be the effect on U.S. import prices of manufactures of a hypothetical further 10 percent depreciation of the dollar. In assessing the room for further squeezing of foreign profit margins, we review available data on profit margins in export-intensive Japanese manufacturing sectors. Finally, we present our conclusions.

\section{Analytical Framework}

Pass-through can be broadly defined as the extent to which a change in the nominal exchange rate induces a change in the import price. In this analysis we have chosen to focus on the narrower definition of passthrough as the partial derivative of the import price with respect to the 
nominal exchange rate in a model that relates import price to the exchange rate and other variables. We follow established practice in this line of inquiry by using a markup model of price determination. Foreign suppliers are assumed to sell in several markets and to have some degree of control over their price in the U.S. market because of product differentiation or other market imperfections. The typical foreign firm sets the price of its exports to the United States in its own currency $\left(P X^{*}\right)$ at a markup $(\lambda)$ over its marginal cost of production $\left(C^{*}\right)$ :

$$
P X^{*}=\lambda C^{*} \text {. }
$$

The U.S. import price, in dollars, is derived by multiplying through by the foreign currency exchange rate $(E R)$ :

$$
P M^{\$}=E R P X^{*}=E R \lambda C^{*} .
$$

The markup, $\lambda$, is assumed to be variable and to respond to both competitive pressures in the U.S. market and demand pressures in all markets combined. Competitive pressures in the U.S. market are measured by the gap between the competitors' prices in the U.S. market and foreign production costs in dollars, while demand pressure on foreign output is measured by capacity utilization. ${ }^{5}$ Thus, the markup is specified

$$
\lambda=\left[P^{\$} /\left(C^{*} E R\right)\right]^{\alpha}\left(C U^{*}\right)^{\beta},
$$

where $P^{\S}$ is the average U.S. price level of the good in question, and

5. We use a markup model, as do other studies; it implies that supply and demand curves are not infinitely elastic. The classic Bertrand assumption on oligopoly competition is the simplest way to incorporate a competitor's price into the maximizing decision of the firm, as in Fisher (1989). A general presentation of the oligopoly pricing literature as it relates to exchange rates is in Dornbusch (1987). More recent innovations in the literature on market competition focus on other ways of incorporating international competitive pressures into the optimal price. These include pricing strategies to maintain market share (Froot and Klemperer, 1988) and pricing strategies that incorporate both market competition and the fixed costs to establish "beachheads" (Baldwin, 1988).

We include capacity utilization as a proxy for "tightness" in market demand that could come from either domestic or foreign markets. Suppose overall market demand increases. Production increases more quickly than does capacity, and firms recognize that they are nearing the potential output of the factory (at this point, in theory, the supply curve becomes vertical). The firms can take advantage of greater market power as they near full capacity by increasing markups. On the other hand, if market demand falls, capacity becomes slack, and firms are willing to cut markups to maintain sales and market share. Thus we expect the sign of $\beta$ (on capacity utilization) to be positive. One factor we do not distinguish here is whether it matters to the exporting firm which market (domestic or 
$C U^{*}$ is the capacity utilization of the foreign firm. Substituting equation 3 into equation 2 and taking the logarithm of the result yields

$$
p m^{\$}=e r+\alpha\left(p^{\S}-e r-c^{*}\right)+\beta c u^{*}+c^{*},
$$

which, after rearranging, yields

$$
p m^{\S}=(1-\alpha) e r+\alpha p^{\S}+(1-\alpha) c^{*}+\beta c u^{*},
$$

where lowercase letters denote logarithmic values.

The pass-through coefficient, or the partial derivative of $p m^{\S}$ with respect to $e r$, is $(1-\alpha)$, where we expect $0<\alpha<1$. At one extreme, where the foreign firm prices to the U.S. market (or is a price taker in a competitive U.S. market) so that $\alpha$ is equal to one, pass-through is zero. In this case, as can be seen in equation 5, holding $c u^{*}$ unchanged, the foreign firm sets the U.S. import price equal to the U.S. domestic price, and changes in exchange rates and foreign costs have no effect; that is, the markup absorbs the shock to the exchange rate or foreign costs. At the opposite extreme, where the foreign firm does not face competition in the U.S. market and $\alpha$ is equal to zero, changes in the exchange rate, as well as foreign costs, are passed through completely, and the markup is left unchanged. For example, rewriting equation 4 as

$$
p m^{\$}-e r-c^{*}=\alpha\left(p^{\$}-e r-c^{*}\right)+\beta c u^{*},
$$

expresses the markup (or profit margin) on sales to the U.S. market as a function of capacity utilization and the gap between the U.S. price (in foreign currency) and foreign cost. When $\alpha$ is close to one (pass-through is low), a rise in er (depreciation of the dollar) results in a decline in foreign profit margins.

The model as specified thus far has several important limitations. The first is that it is a partial-equilibrium model. We have defined passthrough as a partial derivative that reflects the willingness (or lack thereof) of foreign firms to adjust their profit margins to offset changes

foreign) is the primary contributor to market tightness. We avoid this potentially important issue by examining only the export price for the product, and not the gap between the export price and the domestic price, as is considered by Marston (1989).

Another important factor affecting markups is the presence of quantitative restraints. Hooper and Mann (1989b) and Bhagwati (1988) show how quantitative restraints on imports might affect the pass-through of exchange rate changes into profit margins and import prices. 
in exchange rates. A more general model might take into account other, less direct, effects of exchange rates on the import price, through their effects on the other determinants of import prices. To the extent that a depreciation of the dollar lowers foreign costs or reduces U.S. demand (hence depressing foreign capacity utilization), for example, the "total" pass-through will be less than indicated by the partial derivative we analyze. (The impact of a depreciation on the U.S. price level could, of course, work in the opposite direction, to increase total pass-through.) A more general model, for example, would express foreign costs as a function of the exchange rate and other factors $\left(c x^{*}\right): c^{*}=-\phi e r+c x^{*}$, where $\phi$ is greater than 0 (that is, for example, an increase in $e r$ or a depreciation of the dollar lowers the cost of imported raw materials and energy to countries whose currencies are appreciating). Substituting this expression into equation 5 and rearranging yields

$$
p m^{\S}=(1-\alpha-\phi+\alpha \phi) e r+\alpha p^{\S}+(1-\alpha) c x^{*}+\beta c u^{*} .
$$

Since $\phi$ is positive (and given $\alpha<1$ ), the pass-through coefficient in this case $(1-\alpha-\phi+\alpha \phi)$ is less than in the case where $c^{*}$ is treated exogenously $(1-\alpha)$.

In reviewing the data in the next section we note instances where the effects of exchange rates on foreign costs may have been significant. However, our empirical analysis treats foreign costs exogenously; that is, we focus on the extent to which exchange rate changes are absorbed into foreign profit margins. We leave development of a more general empirical model of import prices to future research.

The second limitation of the model is that it is static. The pass-through of a given exchange rate change may well change over time. In particular, firms may be willing to squeeze their profit margins initially in response to a decline in the dollar, but not indefinitely. If profit margins were returned gradually to desired levels, other things being equal, passthrough would tend to build up gradually over time. To allow for this possibility, we specify the import price (and profit margin) equations with a distributed lag on the competitiveness coefficient, $\alpha: \alpha_{0}, \alpha_{1}, \ldots$, $\alpha_{T}$. In this case, the short-run pass-through coefficient (or the contemporaneous effect of the exchange rate on the import price) would be $\left(1-\alpha_{0}\right)$; long-run pass-through would be $\left(1-\sum_{i=1}^{T} \alpha_{i}\right)$. Under a scenario in which pass-through increased gradually over time, and eventually was complete, the initial coefficient, $\alpha_{0}$, would be close to one and subsequent values of $\alpha_{i}$ would be smaller and negative, so that $\sum_{i=0}^{T} \alpha_{i}$ 
would approach zero as time went by. Thus, markups would respond immediately to a shift in the exchange rate, but over time would return to their original levels.

Third, the model that we have specified is restrictive in that it imposes the same rate of pass-through on exchange rates and foreign costs (see equation 5), as well as a consistent effect for U.S. competing prices. Exchange rates tend to be much more variable over time than production costs or U.S. prices. Firms may be more willing to absorb into their profit margins changes in exchange rates (under the expectation that they are likely to be reversed in the near future) than to absorb changes in costs or U.S. prices, which are more likely to be sustained. Accordingly, we estimate versions of the price equation that relax these restrictions on the exchange rate, cost, and U.S. price coefficients.

In fact, we estimate three versions of the model, each relaxing successively more restrictions. The first, and most restrictive, form is an equation that imposes all of the cross-coefficient restrictions in equation 5, but allows for lags in the $\alpha$ coefficient. The constraints are imposed by estimating the profit margin equation (equation 6 ), rewritten as

$$
p m_{t}^{\$}-e r_{t}-c_{t}^{*}=\sum_{i=0}^{T} \alpha_{i}\left(p^{\$}-e r-c^{*}\right)_{t-i}+\beta c u_{t}^{*} .
$$

This constrained form of the model can also be written

$$
p m_{t}^{\S}=\left(e r+c^{*}\right)_{t}+\sum_{i=0}^{T} \alpha_{i}\left(p^{\S}-e r-c^{*}\right)_{t-i}+\beta c u_{t}^{*} .
$$

The second, less restrictive, form allows the coefficient on $p_{t-i}^{\$}$ to differ from $\alpha_{i}$ :

$$
p m_{t}^{\$}=\left(e r+c^{*}\right)_{t}-\sum_{i=0}^{T} \alpha_{i}\left(e r+c^{*}\right)_{t-i}+\sum_{i=0}^{T} \gamma_{i} p_{t-i}^{\$}+\beta c u_{t}^{*}
$$

The third, least restrictive, form allows the coefficients on $c_{i}^{*}$ to differ from $\alpha_{i}$ as well:

$$
\begin{aligned}
p m_{t}^{\$}= & \left(e r+c^{*}\right)_{t}-\sum_{i=0}^{T} \alpha_{i} e r_{t-i} \\
& -\sum_{i=0}^{T} \delta_{i} c_{t-i}^{*}+\sum_{i=0}^{T} \gamma_{i} p_{t-i}^{\$}+\beta c u_{t}^{*} .
\end{aligned}
$$


Equation 7 was estimated in the form shown. Equations 8 and 9 were estimated after consolidating cost and exchange rate terms on the righthand side. Thus equation 8 became

$$
p m_{t}^{\S}=\sum_{i=0}^{T} \eta_{i}\left(e r+c^{*}\right)_{t-i}+\sum_{i=0}^{T} \gamma_{i} p_{t-i}^{\$}+\beta c u_{t}^{*},
$$

where the short-run pass-through coefficient, $\eta_{0}$, is equal to $\left(1-\alpha_{0}\right)$ in equation 8 , and the long-run pass-through coefficient, $\Sigma_{i=0}^{T} \eta_{i}$, is equal to $\left(1-\sum_{i=0}^{T} \alpha_{i}\right)$. Similarly, equation 9 became

$$
p m_{t}^{\$}=\sum_{i=0}^{T} \eta_{i} e r_{t-i}+\sum_{i=0}^{T} \pi_{i} c_{t-i}^{*}+\sum_{i=0}^{T} \gamma p_{t-i}^{\$}+\beta c u_{t}^{*},
$$

where $\pi_{0}=\left(1-\delta_{0}\right)$ and $\Sigma_{i=0}^{T} \pi_{i}=\left(1-\Sigma_{i=0}^{T} \delta_{i}\right)$. The constraints embodied in the fully constrained version of the model (equations 7 and $\left.7^{\prime}\right)$ can be expressed in terms of the coefficients of the unconstrained version (equation $9^{\prime}$ ) as $\eta_{0}=\pi_{0}=1-\gamma_{0}$, and $\eta_{i}=\pi_{i}=-\gamma_{i}$ for all $i \neq 0$.

\section{Data}

The selection of data for analyzing exchange rate pass-through can make a substantial difference to the analysis. In this section we describe the data we have chosen and compare them with data in other studies.

\section{Import Prices and U.S. Domestic Prices}

For the total import price of manufactured goods we use a fixedweighted average (using 1982 import share weights) of import prices for capital goods, automotive products, consumer goods, and industrial supplies excluding petroleum and products. As indicated in figure 1, this series and the fixed-weighted index for total nonoil imports have risen considerably more in recent years than the implicit deflator for nonoil imports. The implicit deflator, with its variable quantity weights, gives a rapidly increasing weight to computers, whose prices, as measured by the Bureau of Economic Analysis, have been falling sharply in recent years. ${ }^{6}$ We prefer the fixed-weight index in part because it measures

6. BEA does not have a price index for imports of computers, but uses a hedonic price index for domestic computers in its place. 
Figure 1. U.S. Import Prices, 1980-88

Index, 1980:1 = 100

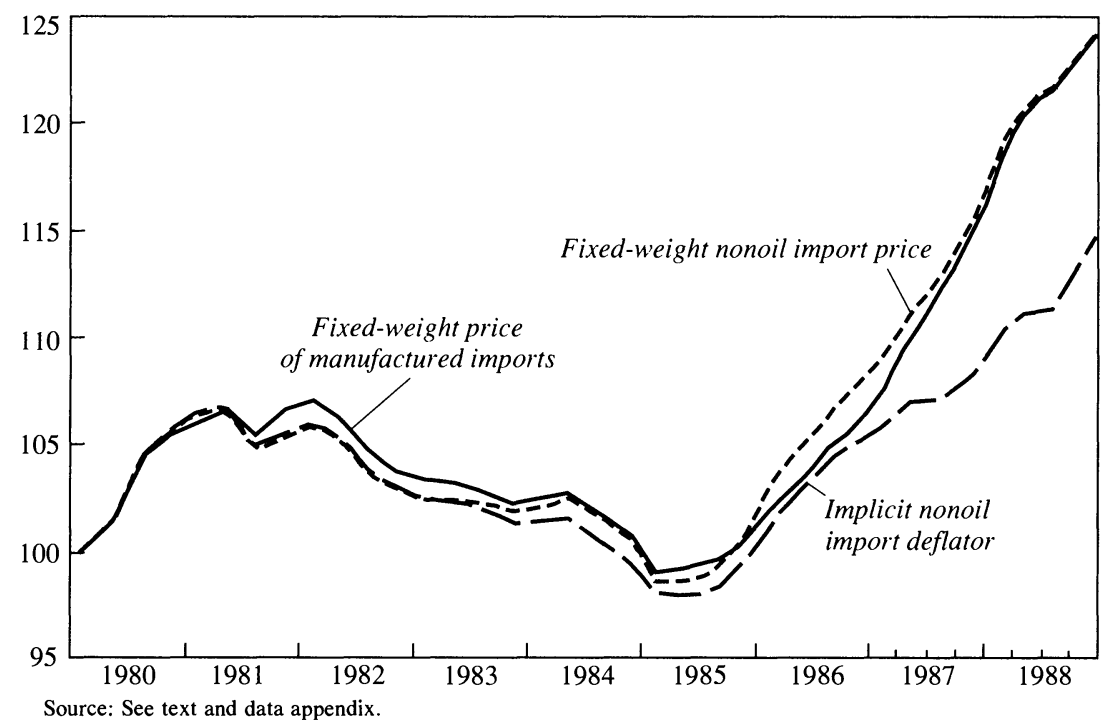

price changes alone (that is, it abstracts from shifts in the commodity composition of imports) and in part because it gives a relatively low weight (reflecting 1982 trade shares) to computers.

For the price index of manufactured imports from Japan, we use an unpublished series constructed by the Bureau of Labor Statistics. Because import price data (other than unit values) were available only on a quarterly basis (until January of this year), our analysis is limited to quarterly observations.

The U.S. domestic "competing" price is a weighted average of producer price indexes for various manufacturing sectors weighted by shares in U.S. imports.

\section{Selection of Foreign Countries and Aggregation of Foreign Data}

Because of the considerable effort involved in constructing cost and other data for foreign countries, as well as severe limitations in data availability in a number of cases, we were constrained to a relatively small sample of foreign countries. The list, shown in table 1 , includes the top nine suppliers of U.S. imports of manufactured goods during the 1980s. These countries accounted for more than 75 percent of these 
Table 1. Shares of Total U.S. Imports of Manufactured Goods, Sample of Nine Countries, 1973-87, Selected Years

Percent

\begin{tabular}{lrrrr}
\hline \multicolumn{1}{c}{ Country } & 1973 & 1978 & 1982 & 1987 \\
\hline Canada & 24.8 & 19.6 & 23.9 & 16.2 \\
United Kingdom & 6.7 & 3.6 & 3.3 & 4.1 \\
West Germany & 11.5 & 7.6 & 8.1 & 8.1 \\
France & 3.1 & 3.2 & 3.1 & 2.9 \\
Italy & 3.6 & 3.1 & 3.3 & 3.0 \\
Japan & 20.5 & 24.6 & 21.0 & 25.9 \\
Korea & 2.1 & 3.7 & 3.2 & 5.3 \\
Taiwan & 3.7 & 5.8 & 4.4 & 7.6 \\
Mexico & 2.6 & 3.6 & 2.9 & 4.1 \\
Total & 78.6 & 74.8 & 73.2 & 77.2 \\
\hline
\end{tabular}

Sources: Data for 1973 from Social and Economic Statistics Administration (1973), table 4. Manufactured goods are the total of categories 5 (chemicals), 6 (manufactured goods), 7 (machinery and transport equipment), and 8 (miscellaneous manufactured articles). Data for the years 1978, 1982, and 1987 from Department of Commerce, Bureau of Economic Analysis, Trade by End-Use tables (unpublished). Manufactured goods are defined as total imports less foods, feeds, and beverages; fuels and lubricants; all other (not elsewhere specified); and crude materials, with manufactured foods, feeds, and beverages added back in (that is, wine and alcohol, and other nonagricultural goods).

imports over the sample period, from the beginning of 1973 through July 1988.

The distribution of imports across these sources has shifted substantially over the past 10 years, as indicated in the table. Canada's share has fallen sharply, and Europe's share by a lesser amount, while the shares of Japan, Korea, and Taiwan have risen commensurately. In light of these shifts in composition, we elected to use variable, current-importshare weights in aggregating foreign data across countries. ${ }^{7}$ Indexes of aggregate foreign variables were constructed as geometrically weighted averages using these variable weights.

\section{Foreign Capacity Utilization}

Capacity utilization rates in manufacturing were collected from national sources where available. In cases where data were unavailable,

7. Using variable weights to aggregate foreign costs and exchange rates across countries is not incompatible with using a fixed-weighted index of import prices because of the way import price data are sampled. The price data do not distinguish country of origin, so that a shift from a high-cost supplier (country) to a low-cost supplier from one period to the next will be reflected in a reduction in the fixed-weighted price index. 
proxies were constructed using deviations of output in manufacturing from constructed peak-to-peak trends in output.

\section{Foreign Cost Data}

Our indexes of foreign costs are weighted averages of unit labor compensation in manufacturing and price indexes for raw material and energy inputs into manufacturing. The weights used were 0.65 for labor and 0.35 for materials and energy in all cases. (Where energy and materials were not already aggregated in available price series, weights of 0.1 for energy and 0.25 for materials were used.) These weights were based on a review of input-output tables for six of the countries included. In all cases, the share of labor compensation in the combined total of labor compensation plus domestic and imported raw material and energy inputs into manufacturing was in a range of 60-70 percent.

Unit labor costs for the industrial countries were taken from quarterly data maintained by the International Monetary Fund that is constructed to be consistent with annual data constructed by the BLS. Series for Korea, Mexico, and Taiwan were compiled using compensation, output, employment, and hours worked in manufacturing, obtained from national sources.

Wholesale prices for raw materials and energy were available in most cases, and in some cases indexes specific to inputs into manufacturing were available. In cases where none was available, a neighboring country's index (translated into the local currency) was used.

The aggregate foreign and Japanese cost indexes (in local currencies) and their components are shown in figure 2. Total foreign costs have been fairly flat, and Japanese costs have fallen somewhat, particularly since 1985. Costs have been held down by declining raw material and energy prices, reflecting the downtrend in commodity (especially oil) prices during much of the $1980 \mathrm{~s}$, and by the appreciation of local currencies against the dollar since 1985. Movements in these cost indexes have differed substantially from movements in broader price indexes that are sometimes used as proxies for costs. As indicated in figure 3, foreign consumer prices have risen considerably faster than manufacturing production costs and wholesale prices somewhat faster, in recent years. The difference between CPIs and manufacturing costs does not necessarily reflect movements in profit margins alone. Much of the 
Figure 2. Foreign Production Costs in Local Currencies, 1973-88

Index, 1980:1 = 100

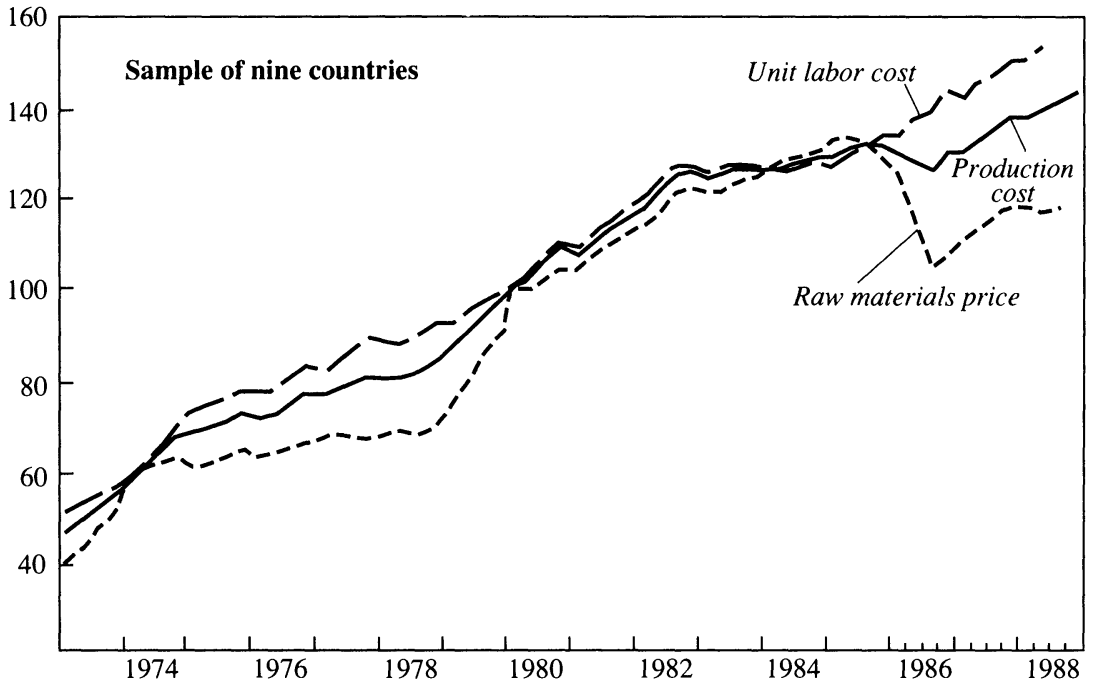

Index, 1980:1 $=100$

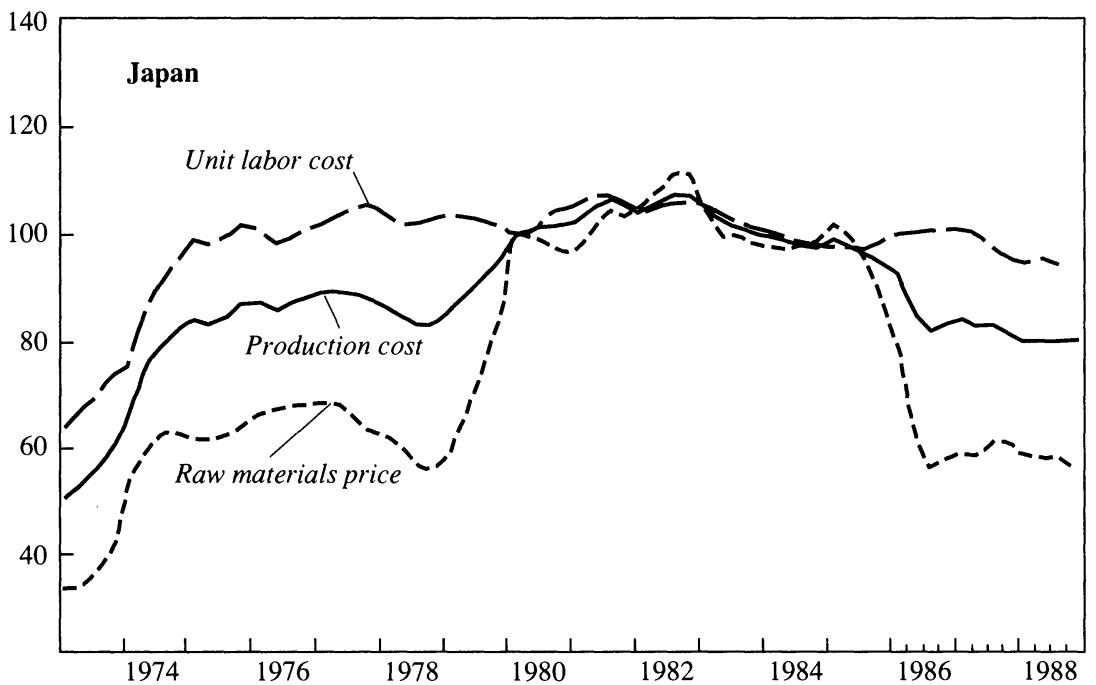

Source: See text and data appendix. 
Figure 3. Foreign Production Costs, WPIs, and CPIs in Local Currencies, 1973-88 Index, 1980:1 = 100

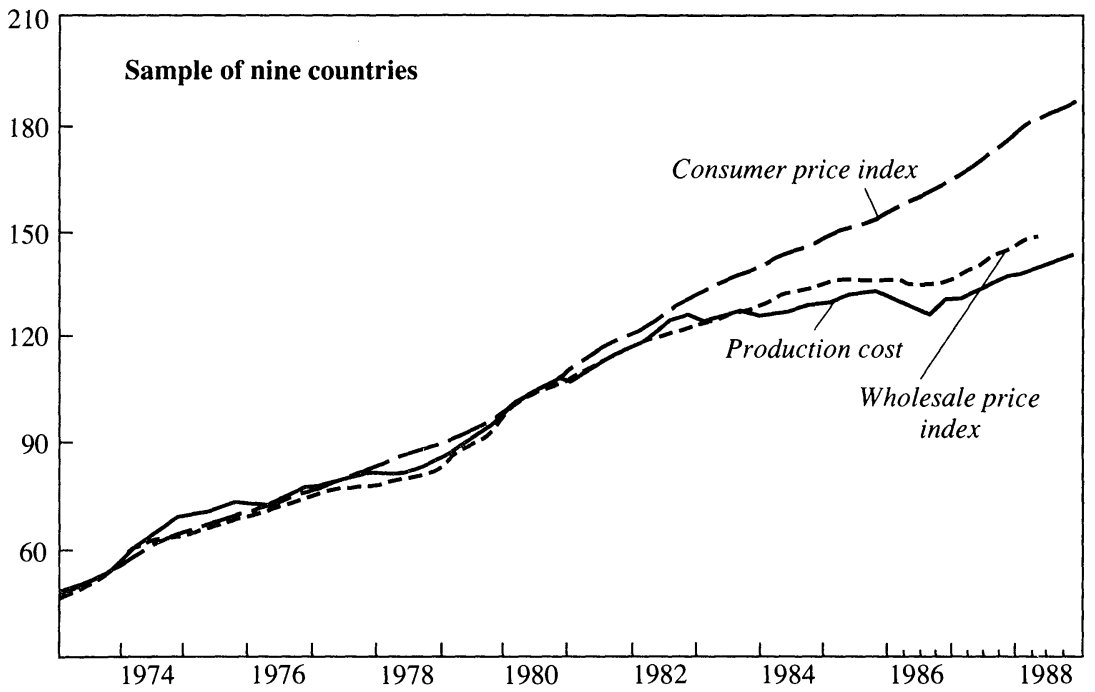

Index, 1980:1 $=100$

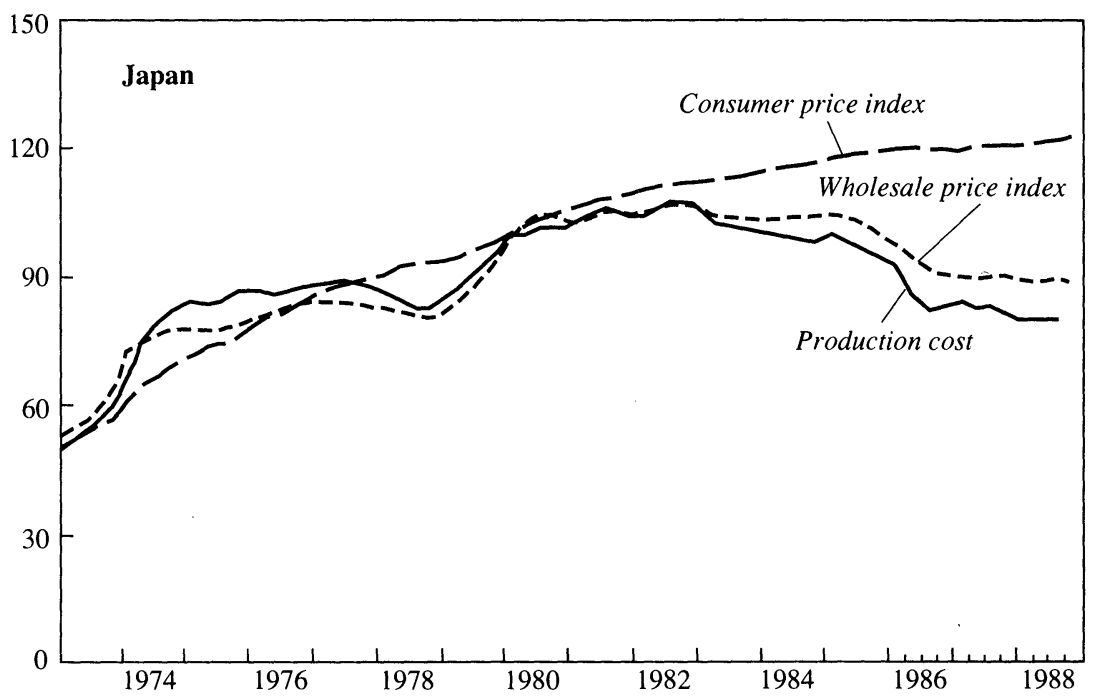

Source: See text and data appendix. 
difference could reflect higher unit labor costs in nonmanufacturing sectors; manufacturing output generally accounts for less than one-third of total output in these countries.

\section{Foreign Profit Margins and Exchange Rates}

Rough estimates of movements in profit margins on the exports of most of the countries included in our sample are illustrated by the gaps between export prices and production costs, shown in the eight panels of figure 4. German profit margins have been much less variable than Japanese profit margins, consistent with the results of a number of previous studies. ${ }^{8}$ In the Japanese case, margins on exports to the United States appear to be more variable than margins on exports to all countries (that is, the gap between Japanese costs and total Japanese export price is less variable than the gap between those costs and the price of exports to the United States). Among the other countries shown, Korean profit margins stand out as having been particularly variable.

Figure 5 shows the same price and cost data for the weighted average of foreign countries, along with the U.S. import price. It is noteworthy that foreign production costs, on average, have risen considerably faster than U.S. import prices since the dollar peaked in early 1985, but roughly in line with total foreign export prices. This suggests the possibility of significant price discrimination, although it could also reflect differences between the compositions of exports to the United States and elsewhere, as well as the influence of countries that are not included in our sample.

The movements in estimated profit margins based on these data can be seen more clearly in figure 6, which plots the ratio of U.S. import prices to foreign costs. As shown in the top panel, during the 1980s this ratio generally has moved in the same direction as the dollar, with foreign profit margins rising as the dollar was appreciating, and falling, on balance, as the dollar fell. On this basis, in mid-1988 profit margins abroad were not substantially below their average level during the 1970 s.

8. See Branson (1972); Kreinin (1977); Magee (1974); Helkie and Hooper (1987). These studies use data aggregated across destination. Knetter (1989), using data disaggregated by industry and by product, suggests that German pricing behavior toward the U.S. market is quite different from its pricing behavior in general. It is the relatively small weight of the United States as a destination for German exports that makes these two results consistent. 
Figure 4. Dollar-denominated Foreign Export Prices and Production Costs in Manufacturing, by Country, 1973-88

Index, 1980:1 = 100

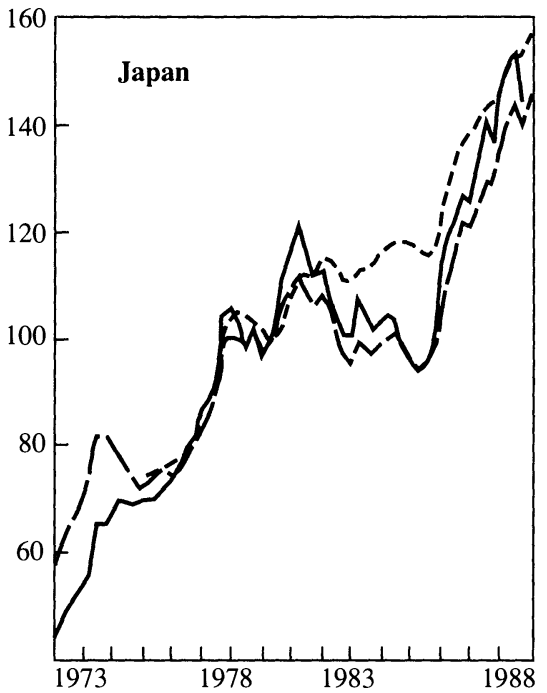

Index, 1980:1 = 100

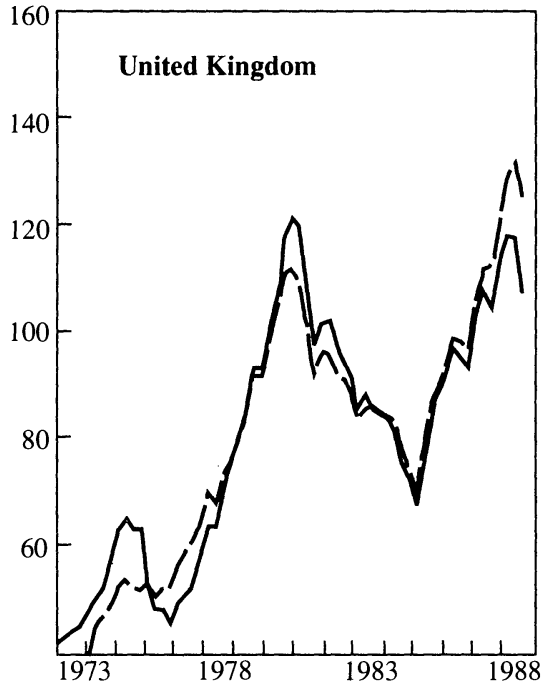

Index, 1980:1 = 100

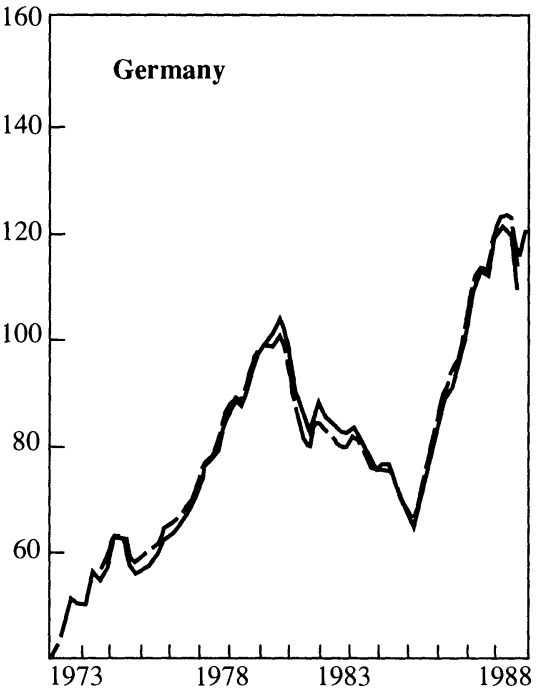

Index, 1980:1 = 100

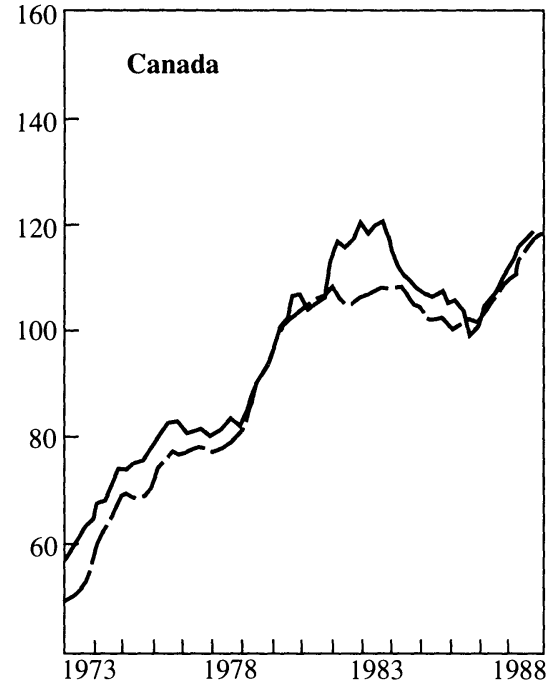

Production cost $\quad-$ Total export price

- - - Price of exports to the United States Source: See text and data appendix. 
Figure $\mathbf{4}$ cont.
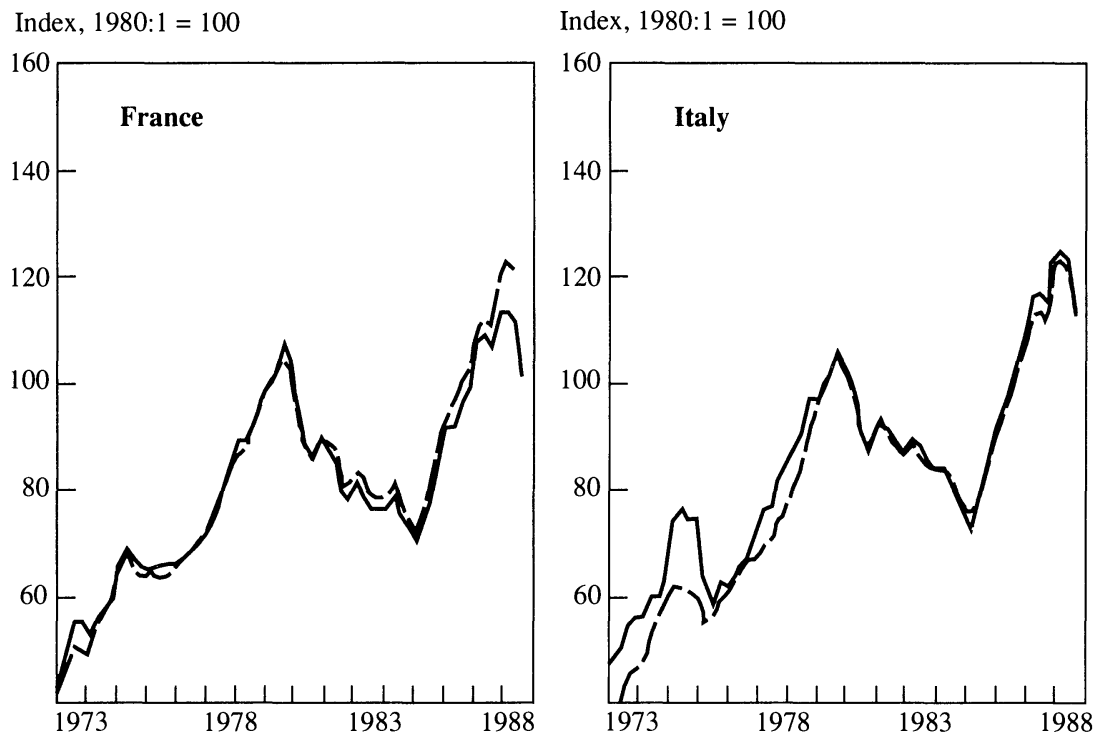

Index, 1980:1 = 100

Index, 1980:1 = 100
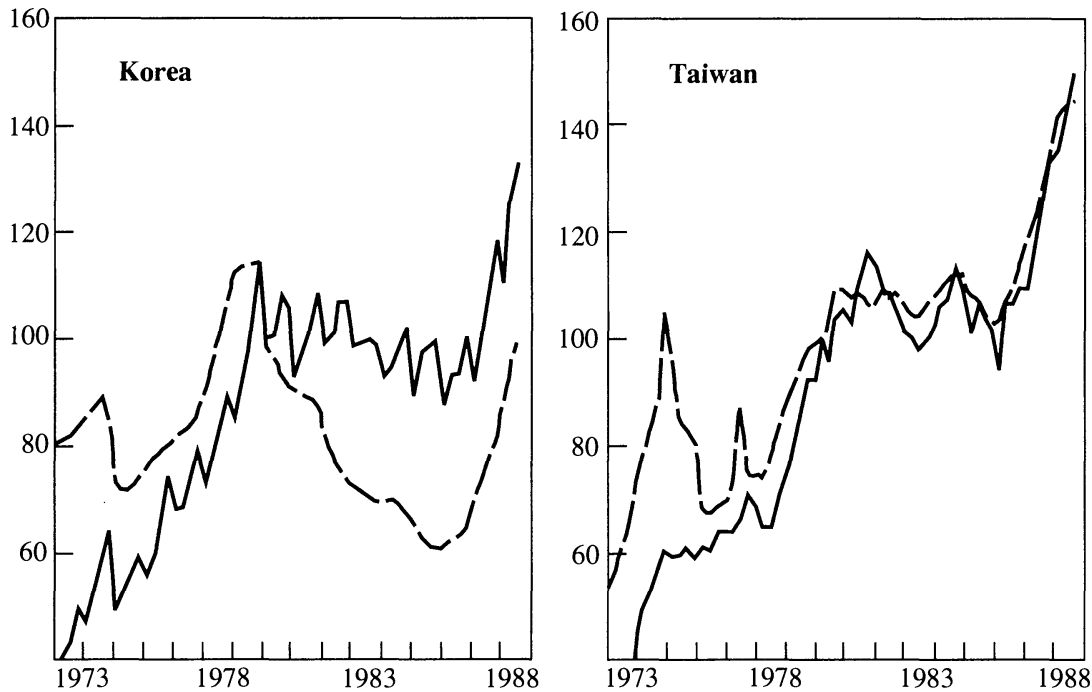

- Production cost

- Total export price 
Figure 5. Dollar-denominated U.S. Import Price, Foreign Production Cost, and Export Price for Manufactured Goods, 1973-88

Index, 1980:1 $=100$

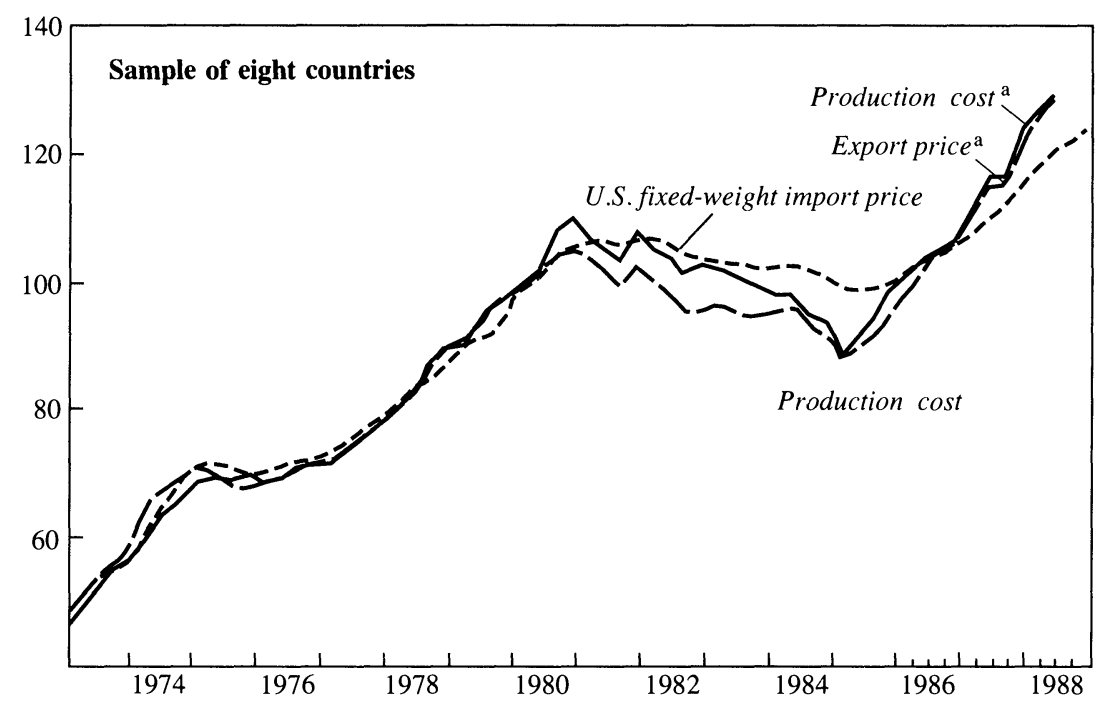

Source: See text and data appendix.

a. Excludes Mexico, for which historical data on export prices of manufactured goods are incomplete.

Also shown in the top panel, for comparison, are ratios of the U.S. nonoil import deflator to foreign CPIs in dollars and to foreign WPIs in dollars, both of which have been used in previous studies as proxies for foreign costs. These ratios suggest a rather different picture of the relationship between exchange rates and foreign profit margins on sales to the United States than does our own constructed measure of these profit margins. Foreign wholesale prices and especially consumer prices have been rising substantially faster than foreign production costs since 1985, while the nonoil import deflator has been rising much more slowly than the fixed-weight index of manufactured imports, thus accentuating the apparent shift in profit margin behavior.

The bottom panel of the chart shows profit margins for Japanese exports to all countries and to the United States. The margin on exports to the United States (the dotted line) rose in the early 1980s and fell thereafter, to about the level prevailing in the 1970 s. In contrast, margins on total exports (the solid line) were much more stable over the 1980s. This difference suggests that when profit margins on Japanese exports 
Figure 6. Exchange Rates and Foreign Profit Margins, 1973-88

Index, 1980:1 $=100$

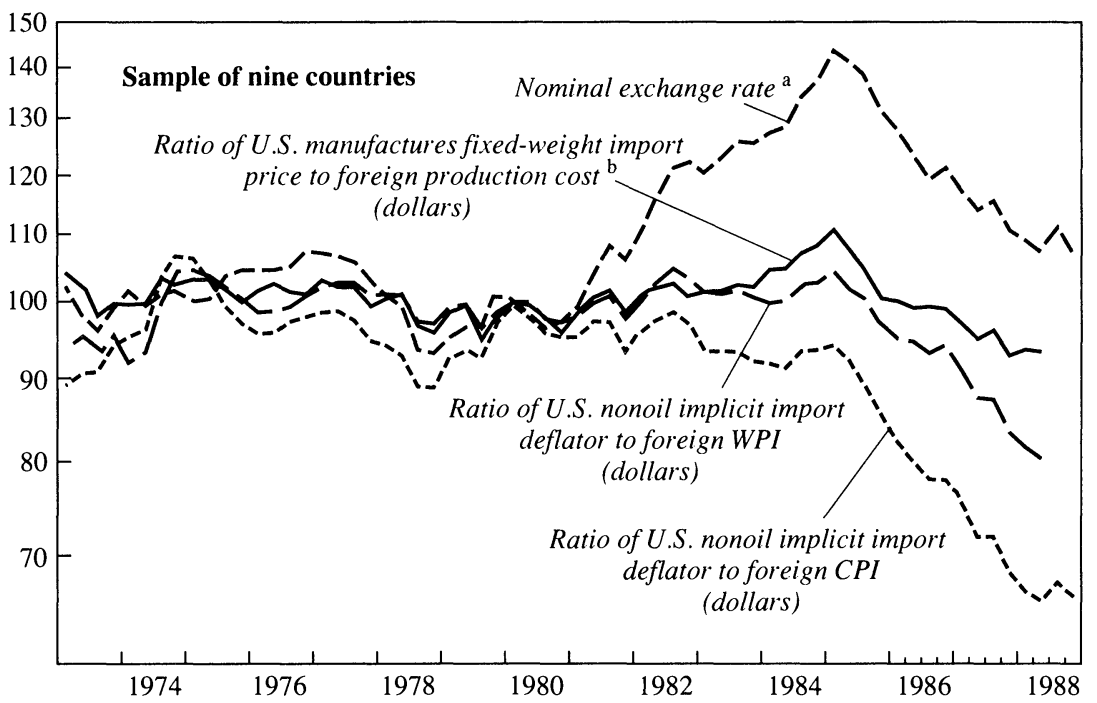

Index, 1980: $1=100$

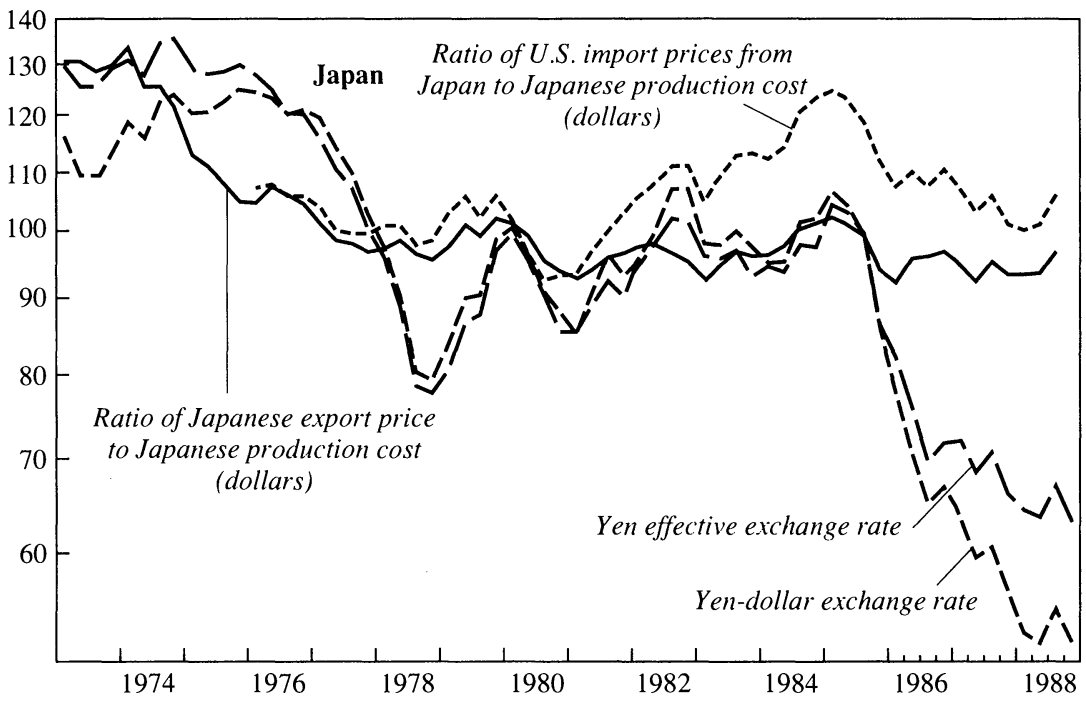

Source: See text and data appendix.

a. Foreign currency per dollar.

b. Based on foreign costs including Mexico. 
to the United States were falling (after early 1985), their margins on exports to other regions were rising. This would have been the case, for example, if Japanese firms priced to market in countries whose currencies were rising against the yen when the dollar was falling against the yen. The chart also shows both the yen-dollar exchange rate and the yen's effective exchange rate against the currencies of the countries included in our study, weighted by Japanese export shares. The yen did appreciate noticeably less on an effective basis than it did against the dollar, and this difference can explain at least some of the difference in the behavior of profit margins on exports to the United States and exports to all countries.

\section{Empirical Estimation}

This section discusses the estimation of equations $7,8^{\prime}$, and $9^{\prime}$ and the implications of these results for exchange rate pass-through. We employ ordinary least squares (OLS) estimation with polynomial distributed lags (PDLs) and correction for serial correlation (SCC) to facilitate comparison of our results with previous work. We also consider estimates using error correction estimation techniques. The hypothesis underlying error correction estimation is that the economic processes followed by the independent variables are tied together by more fundamental variables not present in the equation. Nevertheless, these economic relations between the independent variables can be extracted econometrically and exploited to achieve superior estimates of the shortrun coefficients of the model variables.

To test for lags in pass-through, we examined equations estimated with both unconstrained distributed lags (DLs) and polynomial distributed lags (PDL, second-degree, with a tail constraint).${ }^{9}$ The two yielded similar values for both impact and long-run coefficient estimates. The results reported below are for the PDL estimates. We tested for lags ranging from zero to twelve quarters. Significant lags were present in all

9. As discussed above, if pass-through takes place gradually, the coefficient $\alpha_{i}$ in equation 7 will be close to one in the initial period and small and negative thereafter. To allow for this discontinuous lag pattern when using a second-degree polynomial distributed lag (which constrains the shape of lag distribution to a smooth path), the contemporaneous coefficient, $\alpha_{0}$, was estimated unconstrained and the PDL constraint was then applied to the lag coefficients $\alpha_{1}, \ldots, \alpha_{T}$. The same procedure was used in estimating the coefficients $\gamma_{i}$ on $p_{t-1}^{\S}$ in equations $8^{\prime}$ and $9^{\prime}$. 
cases, and the best equation fits, as measured by the corrected $\bar{R}^{2}$ s, were generally obtained for lags in the range of five to seven quarters, somewhat shorter than the eight quarters of conventional wisdom. ${ }^{10}$ For lags of more than five to seven quarters, the long-run pass-through coefficients generally did not change appreciably and the equation fit tended to degenerate.

\section{Estimation Results: Aggregate Manufactured Imports}

The equations were estimated, for both total imports of manufactured goods and imports of manufactured goods from Japan, using quarterly data over the period 1973:1 through 1988:2. The results for equation 7 $\operatorname{are}^{11}$

$$
\begin{gathered}
\left(p m^{\S}-e r-c^{*}\right)_{t}=3.13+0.39\left(p^{\$}-e r-c^{*}\right)_{t 0.5}-0.08 c u_{t}^{*}+\epsilon_{t}, \\
(6.30) \quad(* * *) \\
\bar{R}^{2}=0.9396 ; \text { standard error }=0.0091 ; \rho=0.93(18.4) .
\end{gathered}
$$

The results suggest that the long-run effect of a 10 percent depreciation of the dollar is to lower markups 4 percent (or raise import prices 6 percent), suggesting substantially less than full pass-through. The shortrun coefficient (not shown) suggested 20 percent pass-through on impact. The coefficient on the capacity utilization term in this case, as in the next two equations, is not statistically significant.

The results for equation $8^{\prime}$, which relaxes the constraint that firms respond the same way to changes in U.S. competing prices as they do to changes in their costs and exchange rates, are

$$
\begin{gathered}
p m_{t}^{\$}=0.62+0.54\left(c^{*}+e r\right)_{t_{0,7}}+0.33 p_{t_{0,7}}^{\$}-0.02 c u_{t}^{*}+\epsilon_{t}, \\
(2.38)(12.68) \quad(* * *) \quad(0.32) \\
\bar{R}^{2}=0.9980 ; \text { standard error }=0.0069 ; \rho=0.30(2.30) .
\end{gathered}
$$

The long-run effect on import prices of changes in the exchange rate and foreign costs is 0.54 , roughly the same as implied by equation 7 . The

10. However, the lags we found are longer than those reported by Mann and Meade (1987); Magee (1974); Mastropasqua and Vona (1988); and Spitaller (1980). Interestingly, they are about the same length as those noted by Branson (1972) reporting on work by Grimm more than 15 years ago.

11. Numbers in parentheses under the coefficient estimates are $t$-statistics; $\left({ }^{* * *}\right)$ denotes cases where individually estimated contemporaneous and lagged coefficients were generally statistically significant at the 95 percent level. 
impact coefficient on the U.S. competing price (not shown) is 0.66 , indicating that foreign firms do match changes in U.S. prices to a substantial degree in the short run. However, the coefficient on that term declines to 0.33 in the long run, suggesting that the price-taking behavior of foreign firms weakens over time.

The results for equation $9^{\prime}$, the fully unconstrained version of the model, which allows the firm to react differently to shocks to costs, exchange rate, or competitor's price, are

$$
\begin{aligned}
& p m_{t}^{\$}=3.24+0.51 c_{t 0,7}^{*}+0.58 e r_{t 0,7}+0.37 p_{t 0,8}^{\$}-0.01 c u_{t}^{*}+\epsilon_{t}, \\
& \begin{array}{lll}
(11.67) & (4.97) \quad(12.96) \quad(* * *)
\end{array} \\
& \bar{R}^{2}=0.9982 ; \text { standard error }=0.0067 ; \rho=0.42(3.37) \text {. }
\end{aligned}
$$

The coefficients in this case are quite similar to those obtained in equation $11 .{ }^{12}$

The distributed lag patterns observed in the estimation of equations $7,8^{\prime}$, and $9^{\prime}$ are consistent with the dynamics posited in the case of gradual pass-through. In particular, the estimate of $\alpha_{0}$ in equation 7 is positive and near one (0.8), and subsequent values of $\alpha_{i}$ are small and negative. This result was found for both the unconstrained DL estimation results and the constrained PDL results.

Equation $9^{\prime}$ has been estimated by William Melick with aggregate data using error correction techniques. ${ }^{13}$ The results from the error correction model are generally quite similar to those discussed here.

\section{Results for Japan}

Equations 7, $8^{\prime}$, and $9^{\prime}$ also were estimated using the bilateral U.S.Japanese import price for manufactured goods, and the appropriate Japanese-specific variables for costs, exchange rate, and capacity utilization. The full results are presented in equations 13-15 below, where $J$ modifies those variables that are specific to the U.S.-Japanese equations.

$$
\begin{gathered}
\left(p m^{J}-e r^{J}-c^{J}\right)_{t}=2.72+0.33\left(p^{\$}-e r^{J}-c^{J}\right)_{t_{0,5}}+0.09 c u_{t}^{J}+\epsilon_{t}, \\
(3.16) \quad(* * *) \\
\bar{R}^{2}=0.9616 ; \text { standard error }=0.0148 ; \rho=0.95(20.61)
\end{gathered}
$$

12. A statistical test of the validity of the constraints was mildly rejected, however.

13. The full estimation results, and a more complete discussion of the method, are presented in Melick (1989). 


$$
\begin{aligned}
& p m_{t}^{J}=--1.05+0.72\left(c^{J}+e r^{J}\right)_{t_{0,7}}+0.05 p_{t_{0,7}}^{\$}+0.50 c u_{t}^{J}+\epsilon_{t}, \\
&(2.05)(13.06) \quad(* * *) \quad(4.63) \\
& \bar{R}^{2}=0.9925 ; \text { standard error }=0.0109 ; \rho=0.49(3.58) ; \\
& p m_{t}^{J}= 3.19+0.16 c_{t 0,7}^{J}+0.50 e r_{t 0,7}^{J}+0.33 p_{t 0,8}^{\$}+0.34 c u_{t}^{J}+\epsilon_{t}, \\
&(6.39) \quad(1.17) \quad(8.51) \quad(* * *) \quad(3.23) \\
& \bar{R}^{2}=0.9956 ; \text { standard error }=0.0083 ; \rho=0.09(0.59) .
\end{aligned}
$$

The exchange rate pass-through coefficients in the Japanese case appear to be slightly higher than those for aggregate imports, a finding that runs somewhat counter to anecdotal evidence. Differences also arise with respect to other variables. The capacity utilization variable is significant in the two unconstrained equations in the Japanese case, unlike the aggregate case. This suggests that profit margins on Japanese exports respond to demand pressures at home and abroad, as well as to costs and exchange rate movements. However, the impact coefficient on the U.S. competing price in those two equations (not shown) had the wrong sign. Could it be that the Japanese exporters take advantage of periods of rising U.S. competing prices and an appreciation of the dollar to aggressively expand their market shares? This perverse effect is reversed in the longer run, so that U.S. prices ultimately do have a positive effect on the price of imports from Japan.

\section{Summary of Pass-through Estimates}

The estimates of short-run and long-run exchange rate pass-through derived from the estimated equations are summarized in table 2 . The top panel shows the estimated coefficients for imports of manufactures from all sources; the bottom panel shows the estimated coefficients for imports from Japan. Results based on the three alternative estimating equations, reported from most constrained to least constrained, along with the different estimating methods and lag specifications (noted in column 1), are shown. (Equations 7 and $8^{\prime}$ were not examined using the error correction technique and the Japanese equations were run only PDL.) The short-run (current-quarter) pass-through coefficient is shown in column 2, the long-run coefficient in column 3 , and the length of the distributed lag (in quarters) in column 4.

The similarity of estimates for both long-run and short-run pass- 
Table 2. Estimates of the Effect of a 1 Percent Change in the Nominal Exchange Rate on Prices of Manufactured Imports

Percent

\begin{tabular}{|c|c|c|c|c|}
\hline Equation & $\begin{array}{l}\text { Estimation } \\
\text { method }^{\text {a }} \\
\text { (l) }\end{array}$ & $\begin{array}{l}\text { Short-run } \\
\text { effect } \\
\text { (2) }\end{array}$ & $\begin{array}{l}\text { Long-run } \\
\text { effect } \\
\text { (3) }\end{array}$ & $\begin{array}{l}\text { Lag } \\
\text { length } \\
\text { (4) }\end{array}$ \\
\hline & \multicolumn{4}{|c|}{ Imports from nine sample countries } \\
\hline \multirow[t]{2}{*}{$7^{c}$} & PDL, SCC & 0.21 & 0.61 & 5 \\
\hline & $\mathrm{DL}, \mathrm{SCC}$ & 0.21 & 0.74 & 5 \\
\hline \multirow[t]{2}{*}{$8^{\prime d}$} & PDL, SCC & 0.24 & 0.54 & 7 \\
\hline & $\mathrm{DL}, \mathrm{SCC}$ & 0.22 & 0.55 & 7 \\
\hline \multirow[t]{4}{*}{$9^{\prime} \mathrm{e}$} & PDL, SCC & 0.21 & 0.58 & 7 \\
\hline & $\mathrm{DL}, \mathrm{SCC}$ & 0.21 & 0.46 & 7 \\
\hline & $\mathrm{ECM}^{\mathrm{f}}$ & 0.20 & 0.53 & $\infty$ \\
\hline & \multicolumn{4}{|c|}{ Imports from Japan } \\
\hline $7^{c}$ & PDL, SCC & 0.37 & 0.67 & 5 \\
\hline $8^{\prime d}$ & PDL, SCC & 0.20 & 0.72 & 7 \\
\hline $9^{\prime}$ e & PDL, SCC & 0.22 & 0.50 & 7 \\
\hline
\end{tabular}

a. Estimation methods: ordinary least squares with serial correlation correction (SCC) and distributed lags (DL) or polynomial distributed lags (PDL), or error correction model (ECM). Period is 1973:1-1988:2.

b. Lag lengths are number of quarters not including the contemporaneous quarter. For ECM, the lag is much longer, in principle, because lagged dependent variables are included on the right-hand side of the equation. In practice, the shape of the lagged response using the ECM technique was quite similar to that using the PDL technique.

c. Markup equation (fully constrained).

d. Import price equation (partially constrained).

e. Import price equation (unconstrained).

f. Taken from Melick (1989).

through, across different model specifications, econometric techniques, and geographical source, is striking. Short-run pass-through is a little over 20 percent and long-run pass-through generally ranges from 50 percent to 60 percent.

The behavior of Japanese exporters has received considerable attention both in the media and in empirical research, with some work suggesting that Japanese firms price discriminate in the U.S. market. ${ }^{14}$ The data reviewed above in figures 4 and 6 suggest too that the behavior of prices of Japanese exports to the United States differs noticeably from that of the average price of Japanese exports to all countries.

Our estimates of bilateral exchange rate pass-through for the Japanese case, however, do not differ greatly from the aggregate pass-through estimates (compare the top and bottom panels of table 2). If Japanese firms do discriminate in the U.S. market, it appears they are not alone.

14. Marston (1989); Ohno (1988). 


\section{Testing for Parameter Stability}

In recent years researchers have questioned both the stability of the pass-through coefficient in the import price equation and the stability of the import price equation itself. These studies are difficult to compare because of different estimation techniques and choice of test statistics. Moreover, each uses different proxies for the independent variables (for foreign costs, exchange rates, competing prices, and so forth). Finally, some authors examine the whole equation, while others limit their analysis to certain variables in the equation. On balance, the literature seems to support structural breaks in both the import price equation and the pass-through coefficient in the early 1980s. Our own results on this point are mixed. ${ }^{15}$

We examined both the stability of the import price equation and the stability of the pass-through coefficient. Equation stability was tested by means of a succession of Chow tests, run with the entire sample split at the end of each year beginning in 1978 and going through 1987. Coefficient stability was tested by adding to the equation a second exchange rate term (or combined exchange rate-foreign cost term, and so on) times a 0-1 dummy. These stability tests were run for the three versions of the model using the DL, serial correlation correction (SCC) specification. ${ }^{16}$ We found that both the equation and the pass-through coefficient are stable in equations 7 and $8^{\prime}$. In the least constrained form, equation $9^{\prime}$, there was a significant break in the pass-through coefficient

15. Piggot and Reinhart (1984) and Baldwin (1988) examine the import price equation using statistical methods and reject the hypothesis that the equation is stable. Both find a break around 1982; Baldwin also finds breaks in 1980 and 1983, but only when he uses certain proxies for foreign costs. These studies do not isolate whether the source of the instability is the pass-through coefficient. Mastropasqua and Vona (1988) test for stability of each parameter in an equation that relates the U.S. import price to foreign export prices and exchange rates. They reject the hypothesis that the pass-through coefficient (based on this specification) for industrial country suppliers of exporters to the United States is stable, finding a break in 1982.

Mann (1986), Marston (1989), and Moffet (1989) have examined the pass-through coefficient over various subperiods of the floating rate era. Their results suggests that passthrough has fallen during the 1980s.

16. Technical problems of the standard approach to testing for parameter constancy (that is, putting $0-1$ dummy variables on variables) in equations with polynomial distributed lags prevented us from using the PDL, SCC estimation technique. 
in 1982. Our results differ somewhat from other research on stability, suggesting the importance of the choice of proxy for import prices and foreign costs. ${ }^{17}$ Melick, using the error correction method, finds similar results.

The stability of the import price relationship is illustrated in figure 7 . The figure shows actual values of the fixed-weight import price of manufactured goods and predicted values using the three equations described above, estimated through 1984. (The sample period was picked to coincide roughly with the point at which other studies examined postsample properties of the equation.) When the equations are estimated with the implicit deflator for nonoil imports and foreign consumer prices as a proxy for costs, all the equations (and especially equations 7 and $8^{\prime}$ ) overpredict significantly in the post-sample period, as shown in the bottom of the figure. ${ }^{18}$ When the fixed-weight import price index and our constructed measure of foreign costs are used, however, equations 7 and $8^{\prime}$ do much better in post-sample prediction, and equation $9^{\prime}$ moderately better, as indicated in the top panel of the figure.

\section{Implications of a Further Decline in the Dollar}

One reason for analyzing pass-through is to determine the likely effects on import prices of future changes in exchange rates. Our estimates suggest that a 10 percent decline in the dollar against the currencies of our major trading partners on average, other things being equal, would raise import prices 2 percent initially, and about 6 percent within about a year and a half. This is a partial-equilibrium estimate; the full effects would depend on what the decline in the dollar, as well as the causes of that decline, did to the other determinants of U.S. import prices.

Some analysts have suggested that with foreign profit margins now at abnormally low levels as a result of the depreciation of the dollar between 1985 and 1987, further depreciation would be passed through more fully.

17. We also tested for the stability of the pass-through relationship using the nonoil import deflator and both CPIs and WPIs as proxies for foreign costs. In these cases, stability was rejected in 1982 for both equations $8^{\prime}$ and $9^{\prime}$.

18. This result is consistent with results reported by Baldwin (1988) and Hooper and Mann (1989b). 
Figure 7. U.S. Import Price for Manufactured Goods, Actual and Alternative Model Predictions, $1980-88^{\mathrm{a}}$

Index, 1980:1 = 100

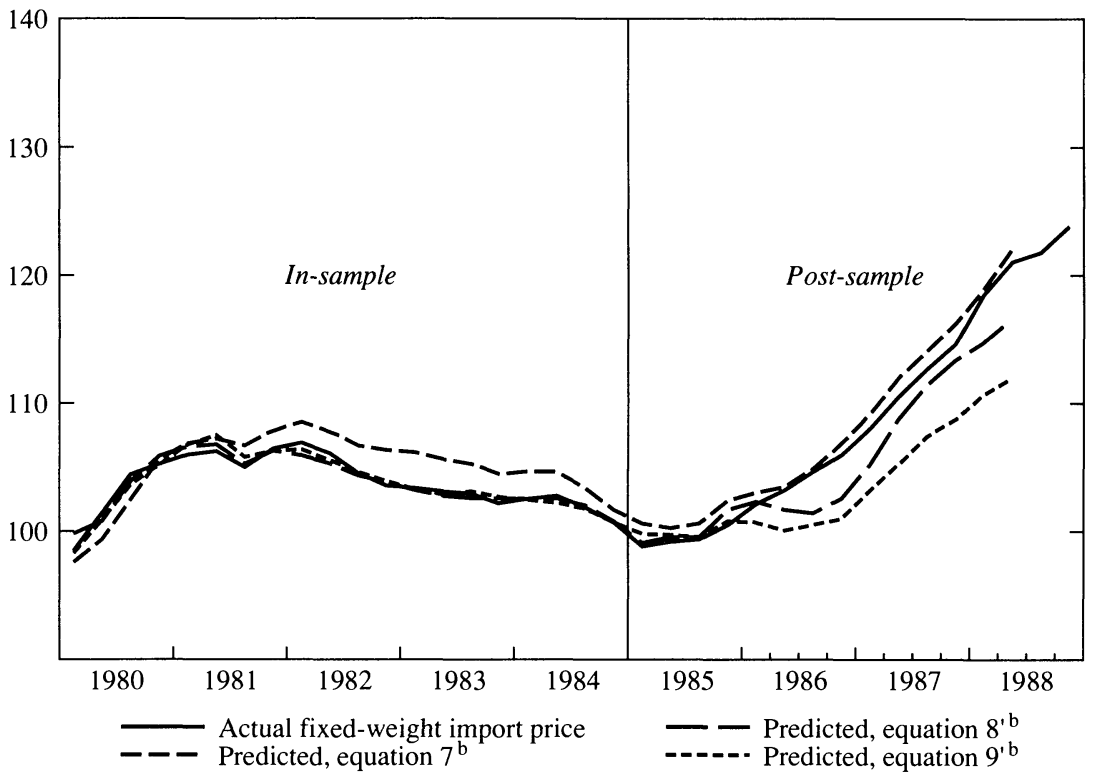

Index, 1980:1 = 100

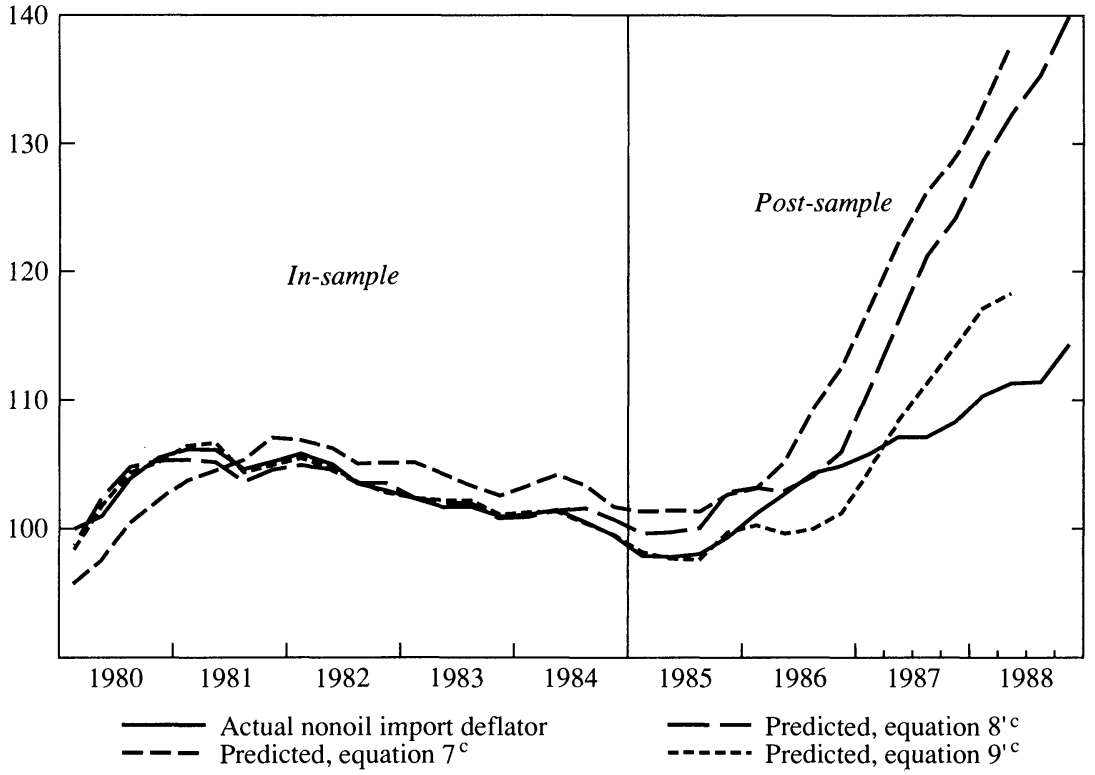

a. Equations estimated over the period 1974:3 to $1984: 4$, using polynomial distributed lag estimation.

b. Equations use a weighted average of unit labor costs and raw materials prices for production costs.

c. Equations use consumer prices as a proxy for production costs. 
This view may have been influenced by estimates of profit margins based on the U.S. import deflator and broad foreign price indexes, as noted earlier. Recall from our discussion of figure 6 that the data we have compiled on costs and import prices suggest, to the contrary, that the current level of foreign profit margins on exports to the United States, on average, is not unusually low relative to the experience of the past 15 years.

To corroborate this view, figure 8 presents Japanese data on the profitability of Japanese industries. The top panel shows the profit-tosales ratios both for all manufacturing and for a group of industries that are export-intensive. (The industries in the latter group and their export intensities, as measured by the ratio of export sales to total sales, are indicated in the bottom panel.) These data suggest that the rise of the yen beginning in 1985 initially did hurt profits, particularly of exportintensive industries. However, the strong recovery of profitability since 1986, despite the continued rise in the yen, indicates that other factors have dominated movements in profit margins in recent years.

One such factor has been the expansion of domestic demand in Japan. A recovery of profit margins for this reason is consistent with our estimation results for Japan, which suggested that capacity utilization rates, which have been rising in Japan, have a significant impact on the prices of Japanese exports to the United States. A second factor was continued weakness, at least through 1988, in the prices of certain raw materials, particularly petroleum, which held down costs.

\section{Conclusions}

We draw the following conclusions from our empirical analysis of the effect of exchange rate changes on U.S. import prices for manufactured goods.

First, some 50 percent to 60 percent of the change in the nominal exchange rate is reflected in prices of manufactured imports. That estimate is indeed lower than those of many previous studies. It is also remarkably robust across alternative functional forms of the import price or profit margin equation and across different estimation techniques.

Second, a pass-through estimate of 50-60 percent suggests that for- 
Figure 8. Profitability of Japanese Manufacturing Industries, 1976-88

Ratio

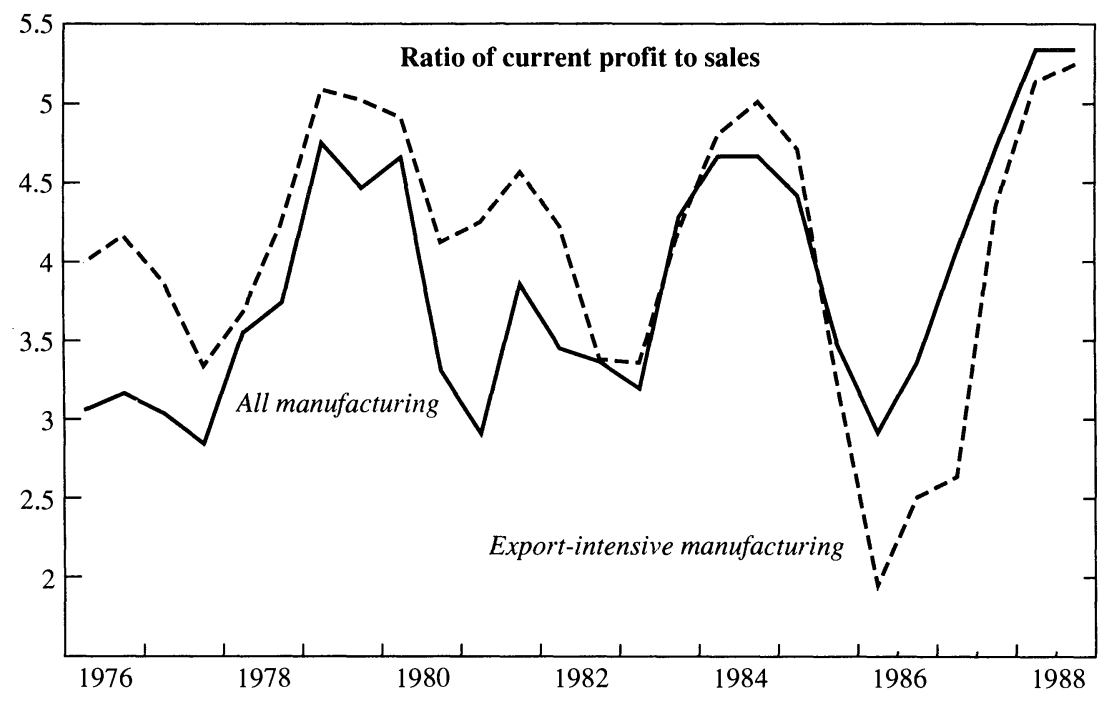

Percent

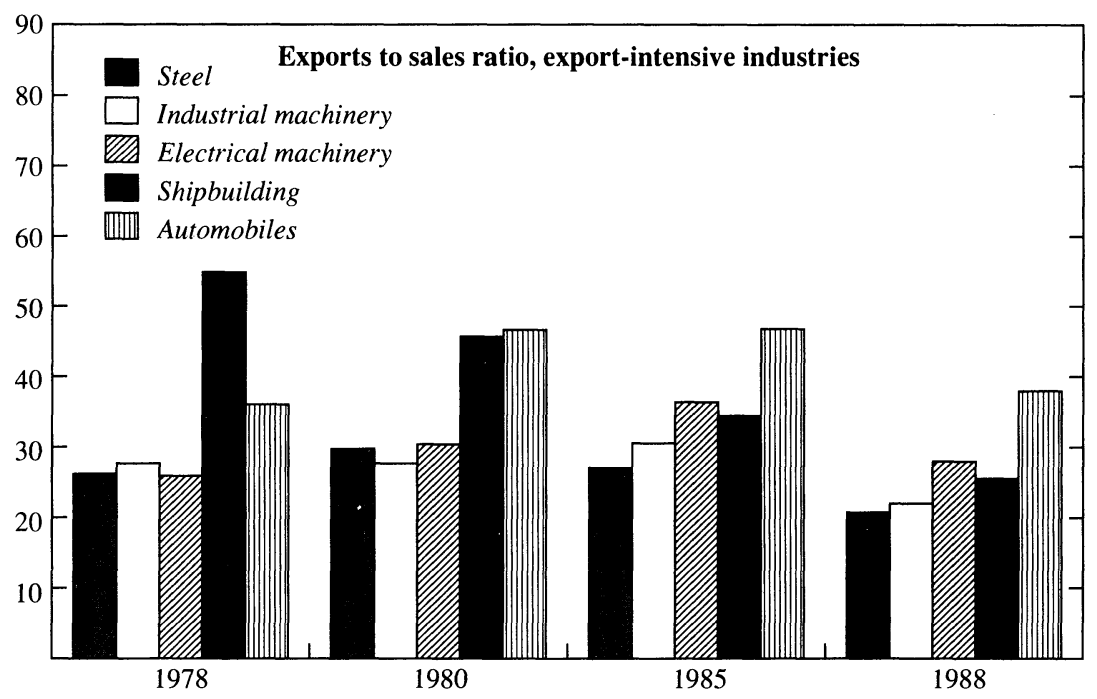

Source: Tankan Quarterly Survey of Japanese Businesses. 
eign firms on average sustain substantial shifts in the profit margins on their exports to the United States as exchange rates change. However, given the tendency of even major changes in exchange rates to be reversed over time, a relatively low pass-through coefficient in the long run does not necessarily imply permanent shifts in profit margins. Moreover, firms may be willing to sustain temporarily lower profits on export sales to maintain market shares, so long as profits on total sales, foreign and domestic, are adequate.

Third, we find little evidence that the pass-through relationship has changed over the past decade. In only one specification of the passthrough equation does it appear that there was a break in the passthrough coefficient. Proper choices of proxies for import prices and foreign costs appear to be important in assessing the stability of the relationship.

Fourth, Japanese firms appear to absorb a higher proportion of exchange rate fluctuations into their profit margins on sales to the United States than they do into margins on their sales to other countries on average. However, the pass-through coefficient for U.S. imports from Japan is about in line with the average for total U.S. imports. This suggests that if Japanese firms price discriminate in the U.S. market they are not alone.

Fifth, as of mid-1988 profit margins on both Japanese and aggregate foreign exports to the United States were not substantially below their average levels during the 1970s and early 1980s, although they had declined from abnormally high levels during the mid-1980s. Japanese survey data on the profit margins of export-intensive industries in that country corroborate these estimates. These findings contradict the view that foreign profit margins have been "squeezed to the bone" by the decline in the dollar.

Sixth, an implication of the above conclusions is that a further decline in the dollar at this juncture would raise import prices by a little over half as much, proportionately, as the change in the dollar. Of course, import prices could respond more strongly if the decline in the dollar took place against a background of profit margins abroad that were being squeezed significantly by, for example, a strong rebound in prices of oil and other raw materials. 
APPENDIX A

\section{Sources of Raw Data by Country}

\author{
Data series \\ Canada \\ Unit labor cost \\ Capacity utilization \\ Price of raw materials and energy
}

Export price (average of end products, inedible, and fabricated materials, inedible)

\section{Japan}

Unit labor cost

Capacity utilization

Price of raw materials and energy

Export price (all commodities)

Germany

Unit labor cost

Capacity utilization

Price of raw materials and energy

Export price (total)
Source

IMF, unpublished

Bank of Canada Review

BLS U.S. price in Canadian dollars, 1973-77

Canadian Economic Observer, 1978-88

Statistics Canada: Summary of Canadian International Trade

IMF, unpublished

Bank of Japan, Economic Statistics Monthly

Bank of Japan, Economic Statistics Monthly

Bank of Japan, Economic Statistics Monthly

IMF, unpublished

Bundesbank, supplement to monthly report

Statistiches Bundesamt, Fach. 17, Reihe 3

Bundesbank, supplement to monthly report

IMF, unpublished

Central Statistical Office, Monthly Digest of Statistics

Central Statistical Office, Monthly Digest of Statistics

Unit value index (total exports)

Central Statistical Office, Monthly Digest of Statistics 
Italy

Unit labor cost

Price of raw materials and energy

Export price (total)

France

Unit labor cost

Industrial production

Price of raw materials and energy

Unit value index (total exports)
Capacity utilization

IMF, unpublished

Bank of Italy calculation (BIS)

Average of German and U.K. prices, in lire

Bollettino Mensile di Statistica

IMF, unpublished

Bulletin Mensuel de Statistiques

Average of German and U.K. prices, in francs

Bulletin Mensuel de Statistiques, 1973-86

After 1986, export price is assumed to grow at the same rate as that of Italy.

Korea

Earnings

Man days

Employment

Industrial production

Price of raw materials and energy

Export price

Taiwan

Monthly earnings

Employment

Monthly hours

Industrial production
Bank of Korea, Economic Statistics Yearbook

Bank of Korea, Monthly Bulletin

Bank of Korea, Economic Statistics Yearbook

Bank of Korea, Monthly Bulletin

Bank of Korea, Economic Statistics Yearbook

Bank of Korea, Monthly Bulletin

Bank of Korea, Economic Statistics Yearbook

Bank of Korea, Monthly Bulletin

Bank of Korea, Economic Statistics Yearbook

Bank of Korea, Monthly Bulletin

Bank of Korea, Economic Statistics Yearbook

Bank of Korea, Monthly Bulletin

Monthly Statistics of the Republic of China

Monthly Statistics of the Republic of China

Monthly Statistics of the Republic of China

Monthly Statistics of the Republic of China 
Price of raw materials and energy

Unit value index (total exports)

Mexico

Hourly labor cost

Industrial production

Price of raw materials and energy

Export price
Korean price, in Taiwan dollars

Monthly Statistics of the Republic of China

Banco de Mexico, Indicadores Economicos

Banco de Mexico, Indicadores

Economicos

U.S. price in pesos

Not available

APPENDIX B

\section{Constructed Data Series}

For Korea, Taiwan, and Mexico, data on unit labor costs were unavailable. The Korean index was constructed by first indexing the series for earnings, man days, employment, and industrial production to 1980:1 = 100. A monthly labor input index was constructed by multiplying employment by man days. An index of output per worker per month was then calculated by dividing the industrial production index by the labor input index. Unit labor costs were defined as total monthly earnings per worker divided by output per worker.

Similar methodology was used to construct unit labor cost indexes for Taiwan and Mexico. For Taiwan, monthly hours worked was substituted for man days, and for Mexico, an index of monthly labor cost was already available, so unit labor costs were defined as monthly labor costs divided by industrial production.

Capacity utilization data were unavailable for the United Kingdom, France, Korea, Taiwan, and Mexico. For each of these countries, an estimate was calculated by applying a peak-to-peak adjustment to the trend industrial production index. For the United Kingdom, the adjustment took into account growth in capital stocks in manufacturing and population as well.

The fixed-weight U.S. manufactures import price index was calculated as the weighted average of fixed-weight import price indexes for four commodity categories, weighted by shares in U.S. imports in 1982 . 
The weights and categories are as follows: industrial supplies and materials excluding petroleum (36.6 percent), capital goods excluding autos (20.0 percent), consumer goods (23.7 percent), and automobiles (19.7 percent). Data are from the Department of Commerce, Bureau of Economic Analysis. The U.S. fixed-weight nonoil import price index is based on 1982 weights for total merchandise imports and petroleum imports from Survey of Current Business, table 7.15.

The U.S. competing price index for manufactured goods was calculated as a weighted average of PPIs for finished consumer goods (41 percent), capital equipment (33 percent), and intermediate materials and components for manufacturing (26 percent), weighted by each category's share in U.S. imports in 1982. Data are from the Bureau of Labor Statistics. 


\section{Comments and Discussion}

William H. Branson: This paper provides an update on empirical estimation of the "pass-through" of fluctuations in the dollar exchange rate to U.S. import prices. The pass-through coefficient is defined here as the coefficient of the exchange rate in an import price equation. The authors extend previous work by Mann and by William Helkie and Hooper, using a fixed-weight import price series and constructing a series for the costs of production of exporters to the United States and extending the data period to 1988. The results are consistent with the earlier estimates by the authors, with a one-quarter pass-through of about 0.2 and a longer-run pass-through of about 0.6 over approximately six quarters. These results are summarized in table 2 of the paper. Rather than picking at the paper's econometrics, which seem fine to me, I will begin with a brief discussion of the role of supply elasticities, then discuss alternative explanations of the apparently incomplete pass-through and behavior of export prices that are consistent with the Hooper-Mann results, and finish with a suggestion for reformulating the theoretical framework for analysis of these issues.

The effect of imperfectly elastic supply of exports to the United States on the apparent pass-through coefficient was discussed in my 1972 paper, in which I estimated the supply elasticity adjustment factor to be about 0.2 . This meant that the elasticity of import prices with respect to the exchange rate would be 0.8 with full pass-through. This supply adjustment factor was used throughout that paper. A similar analysis is given in chart 2 of Catherine Mann's 1986 paper and in a recent paper by Jagdish Bhagwati, which I discuss below. In the Hooper-Mann paper, this effect is discussed around equation $5 \mathrm{a}$, but not carried through to the empirical estimates. In equation 5a, a supply adjustment of 0.2 would 
multiply the coefficient of the exchange rate ( $e r)$ by 0.8 . This means that the coefficients of this variable in the estimated equations 10 through 12 are to be applied to the change in the exchange rate net of the supply adjustment. So in equation 12, for example, the elasticity with respect to the exchange rate including the effect on $c *$ would be 0.464 ( 0.8 times 0.58). A full pass-through coefficient of 1 in the Hooper-Mann equations would give an exchange rate elasticity of 0.8 . This is the benchmark for the expected elasticity of import prices to the exchange rate.

In this paper, Hooper and Mann discuss only briefly, in their introductory remarks and in the concluding section, the reasons for incomplete pass-through in the long run. The usual discussion in the literature, cited in footnote 2 , involves imperfect competition and some story about maintaining market share in the face of exchange rate fluctuations. Jagdish Bhagwati has recently offered a different kind of explanation for the apparently partial pass-through as seen in import price equations. ${ }^{1}$ He argues that as the dollar appreciated from 1980 to 1985, the coverage of U.S. imports by nontariff barriers (NTBs) increased significantly. He cites the World Development Report (1987) as showing an increase in coverage by some 23 percent from 1981 to 1986 , and other studies that show that 15 percent of U.S. imports were covered by voluntary export restraints in 1986 and 40 percent were covered by some NTB or monitoring agreement in 1983. The increase in the coverage of NTBs as the dollar appreciated would hold up import prices. Then as the dollar depreciated from 1985, the premium on NTB-restricted imports would fall instead of import prices rising. Pass-through would imply reduction of the premium on imports rather than rising prices, a pattern consistent with the 1981-88 movement of profit margins relative to the nominal exchange rate shown in Hooper and Mann's figure 6.

Bhagwati does not present a quantitative estimate of the importance of this effect. But it is consistent with the study by Cristina Mastropasqua and Stefano Vona of the Bank of Italy (cited by Hooper and Mann). Following Mann's 1986 paper, they estimate an import price equation for manufactures for the United States that includes separately an average of the dollar export prices of the eight largest exporters to the United States, covering about 72 percent of the U.S. imports, and an 
index of the export unit values of manufactures of the developing countries. With three-quarter lag distributions, for the period from February 1976 to March 1987, they estimate a sum of coefficients of 0.24 for the developing country index and a break in the coefficient for the largest exporters index from 0.88 through May of 1982 to 0.50 after. This suggests a change in the sensitivity of U.S. import prices to nondeveloping country export prices that is consistent with Bhagwati's argument. It also suggests that the negative results of the tests that Hooper and Mann do for coefficient instability might change if they included the developing country index in the equation.

Incomplete pass-through, as defined by Hooper and Mann, will also be reflected in home-currency export prices, with profit margins varying with exchange rates. As the dollar rises against the yen, stable Japanese export prices in dollars imply rising prices and profit margins in yen, and vice versa as the dollar depreciates. Richard Marston and I have found that export prices in Japanese manufacturing follow this pattern and that their behavior differs substantially from that of prices in the same sectors on the domestic Japanese market. ${ }^{2}$

We estimate equations for Japanese yen domestic and export prices for 13 manufacturing sectors, with the equivalent U.S. price times the yen-dollar exchange rate, the competitive U.S. price in yen, as one of the independent variables. If changes in the exchange rate are absorbed in the profit margin with the dollar price unchanged, we expect to see a coefficient near unity for the competitive U.S. yen price in the Japanese export price equation. If Japan can price discriminate between the home and U.S. markets, we expect to see a lower coefficient in the Japanese domestic price equation. In all sectors, we find that the coefficient of the competitive U.S. yen price is larger in the export price equation than in the domestic price equation, suggesting that price discrimination exists. The elasticity of the export price in yen to the yen-dollar exchange rate is in the range of 0.5 to 0.8 , consistent with a pass-through less than 0.5 in the Hooper-Mann framework.

In a companion study on U.S. export and domestic price behavior, Kimberly Reisler finds no sensitivity of U.S. dollar export prices to the dollar-yen exchange rate, implying full pass-through by U.S. exporters. ${ }^{3}$

2. Branson and Marston (1989).

3. Reisler (1989). 
This suggests, or confirms, a difference between U.S. and Japanese pricing behavior. U.S. firms mark up costs, as in the Hooper-Mann model, so pass-through is complete. Japanese firms price to market, that is, they mark down the market price to the profit margin. This implies a much longer lag of trade adjustment to exchange rate changes, since it comes through exit or entry, rather than sales variation by existing firms.

This difference in adjustment response signals to me the need for a reconsideration of the theoretical framework for the analysis of the passthrough question. The model in the Hooper-Mann paper is basically static, taking the change in the exchange rate as one-shot and permanent. It is the same model that I borrowed in 1972 from Charles Kindleberger's 1963 text. ${ }^{4}$ By now, we should be thinking about optimizing price policy for investors and exporters who know that they face an exchange rate that follows some sort of stochastic process over time. There are two extreme examples, which might correspond to the U.S.-Japanese difference in pricing behavior.

The first example is an exchange rate that is stochastic or a moving average around an equilibrium trend, with strong mean reversion. In this case it might be optimal to absorb exchange rate changes in profit margins, and not to pass them through. The second example is an exchange rate that follows a random walk, so that each change is seen to be permanent. In this case, full and immediate pass-through might be optimal. These differences could be consistent with the empirical results for the effective exchange rates of the yen and the dollar. The dollar seems to follow a random walk, consistent with pass-through by U.S. exporters. In figure 6 of Hooper and Mann, the effective rate of the yen seems to adhere to an equilibrium path that shows two major appreciations, one in the mid-1970s and another in the mid-1980s. This could be consistent with pass-through only after changes that are perceived to be permanent. These differences call for a revision of pass-through theory along the lines of time series analysis.

\section{General Discussion}

Robert Lawrence noted that the evidence in this paper showing that foreigners are earning normal profits on their sales to the United States

4. Kindleberger (1963, p. 165). 
contradicts other work that suggests that these profits are exceptionally low. He observed that settling this issue is important for deciding whether the dollar has to fall further since, if foreign margins are currently squeezed, import prices could be expected to rise even without further exchange depreciation. Lawrence also observed that disaggregated data fail to support the Branson-Bhagwati argument that voluntary restraint arrangements (VRAs) explain incomplete pass-through. The prices of automobile imports, which are covered by VRAs, have increased substantially with dollar depreciation, whereas prices have risen only slightly for capital goods imports, a sector free of VRAs. Catherine Mann noted further evidence that VRAs have little price effect: although the Japanese are much more affected by VRAs than are other foreign producers, pass-through by the Japanese and by others appears to be similar.

William Branson suggested that the difference between Japanese export prices to the United States and its total export prices can be explained by different bilateral exchange rate movements. During the 1980s, the effective yen exchange rate remained fairly stable as the dollar first appreciated and then depreciated against the yen. This means that the yen changed against other currencies in the opposite direction to its change against the dollar. As a result, Japanese competitive margins moved in opposite directions on its exports to the United States and its exports to its other trading partners.

James Tobin observed that the markup model of the paper might not always be applicable. A country entering the U.S. market, such as Korea or Taiwan recently, will sell at prices over which it has very little control. The effect of exchange rate changes, then, will be on the quantity they choose to sell in the U.S. market rather than on the price at which they sell. 


\section{References}

Baldwin, Richard E. 1988. "Hysteresis in Import Prices: the Beachhead Effect." American Economic Review 78:773-85.

Bhagwati, Jagdish N. 1988. "The Pass-through Puzzle: The Missing Prince from Hamlet." Columbia University (December).

Branson, William H. 1972. "The Trade Effects of the 1971 Currency Realignments." BPEA, 1:1972, 15-65.

Branson, William H., and Richard C. Marston. 1989. "Price and Output Adjustment in Japanese Manufacturing." Working Paper 2878. Cambridge: National Bureau of Economic Analysis (March).

Clark, Peter B. 1974. "The Effects of Recent Exchange Rate Changes in the U.S. Trade Balance.' In The Effects of Exchange Rate Adjustment, edited by Peter B. Clark, Dennis E. Logue, and Richard James Sweeney. Washington: U.S. Treasury, OASIA Research Department.

Cline, William R. 1989. United States External Adjustment and the World Economy. Washington: Institute for International Economics (forthcoming).

Dornbusch, Rudiger. 1987. "'Exchange Rates and Prices.' American Economic Review 77:93-106.

Fisher, Eric. 1989. "A Model of Exchange Rate Pass-through." Journal of International Economics, forthcoming.

Froot, Kenneth A., and Paul Klemperer. 1988. "Exchange Rate Pass-through When Market Share Matters." Working Paper 2542. Cambridge: National Bureau of Economic Research (May).

Gagnon, Joseph E. 1988. "Adjustment Costs and International Trade Dynamics." International Finance Discussion Papers 321. Washington: Board of Governors of the Federal Reserve System (May).

Helkie, William L., and Peter Hooper. 1987. "The U.S. External Deficit in the 1980s: An Empirical Analysis." International Finance Discussion Papers 304. Washington: Board of Governors of the Federal Reserve System (February).

—. 1989. "U.S. External Adjustment: Progress and Prospects." International Finance Discussion Papers 345. Washington: Board of Governors of the Federal Reserve System (March).

Hooper, Peter, and Barbara R. Lowrey. 1979. "Impact of the Dollar Depreciation on the U.S. Price Level: An Analytical Survey of Empirical Estimates." Staff Study 103. Washington: Board of Governors of the Federal Reserve System (March).

Hooper, Peter, and C. L. Mann. 1989a. "The Emergence and Persistence of the U.S. External Imbalance: 1980-87.'” Princeton Studies in International Finance, forthcoming. 
1989b. "The U.S. External Deficit: Its Causes and Persistence." In U.S. Trade Deficit: Causes, Consequences, and Cures, edited by Albert E. Berger. Boston: Kluwer Academic Publishers.

Isard, Peter. 1974. "The Price Effects of Exchange Rates Changes." In The Effects of Exchange Rate Adjustments, edited by Peter B. Clark, Dennis E. Logue, and Richard James Sweeney. Washington: U.S. Treasury, OASIA Research Department.

Kindleberger, Charles P. 1963. International Economics, 3rd ed. Homewood, Ill.: Richard D. Irwin, 1963.

Knetter, Michael M. 1989. "Price Discrimination by U.S. and German Exporters." American Economic Review 79:198-209.

$\rightarrow$ Kravis, Irving B., and Robert E. Lipsey. 1978. "Price Behavior in the Light of Balance of Payments Theories." Journal of International Economics 8:192-245.

$\rightarrow$ Kreinin, Mordechi E. 1977. "The Effect of Exchange Rate Changes on the Prices and Volume of Foreign Trade." IMF Staff Papers 24:297-329.

Krugman, P. R. 1987. "Pricing to Market When the Exchange Rate Changes.", In Real-Financial Linkages Among Open Economies, edited by S. W. Arndt and J. D. Richardson. Cambridge: MIT Press.

Krugman, Paul R., and Richard E. Baldwin. 1987. "The Persistence of the U.S. Trade Deficit." BPEA, 1:1987, 1-43.

Magee, Stephen P. 1974. “U.S. Import Prices in the Currency-Contract Period.' BPEA, 1:1974, 117-68.

Mann, Catherine L. 1986. "Prices, Profit Margins and Exchange Rates." Federal Reserve Bulletin 72:366-379.

Mann, Catherine L., and E. E. Meade. 1987. "Empirical Analysis of Product Trade: A Disaggregated Approach." Washington: Board of Governors of the Federal Reserve System (November).

Marston, Richard. 1989. "Pricing to Market in Japanese Manufacturing." Wharton School, University of Pennsylvania (March).

Mastropasqua, Cristina, and Stefano Vona. 1988. "The U.S. Current Account Imbalance and the Dollar: The Issue of the Exchange Rate Pass-through.", Banca d'Italia (December).

Melick, William R. 1989. "The Stability of Exchange Rate Pass-through in the 1980s." Washington: Board of Governors of the Federal Reserve System (June).

Moffet, Michael H. 1989. "The J-Curve Revisited: An Empirical Examination for the United States." Journal of International Money and Finance, forthcoming.

Ohno, Kenichi. 1988. "Export Pricing Behavior of Manufacturing: A U.S.Japan Comparison." IMF Working Paper WP-88-78. Washington: International Monetary Fund. 
Piggott, Charles, and Vince Reinhart. 1985. “The Strong Dollar and U.S. Inflation.' FRB of New York Quarterly Review 10:23-29.

Reisler, Kimberly M. 1989. “An Examination of United States Producer Price Reactions to Changes in the U.S.-Japan Exchange Rate." Princeton University senior thesis (April 6).

Social and Economic Statistics Administration, Bureau of the Census. 1973. U.S. General Imports: Schedule A Commodity Groupings: World Area, Country, and Method of Transportation. Washington: Department of Commerce (December).

Spitaller, Erich. 1980. "Short-Run Effects of Exchange Rate Changes on Terms of Trade and Trade Balance." IMF Staff Papers 27:320-348.

Wilson, John F., and Wendy E. Takacs. 1979. "Differential Responses to Price and Exchange Rate Influences on the Foreign Trade of Selected Industrial Countries." Review of Economics and Statistics 61:267-79.

Woo, Wing T. 1984. "Exchange Rates and the Prices of Nonfood, Nonfuel Products." BPEA, 2:1984, 511-30. 